\title{
From widespread Mississippian to localized Pennsylvanian extension in central Spitsbergen, Svalbard
}

\author{
Jean-Baptiste P. Koehl ${ }^{1,2}$ and Jhon M. Muñoz-Barrera ${ }^{3}$ \\ ${ }^{1}$ Department of Geosciences, UiT The Arctic University of Norway in Troms $\emptyset, 9037$ Troms $\emptyset$, Norway \\ ${ }^{2}$ Research Centre for Arctic Petroleum Exploration (ARCEx), UiT The Arctic University of Norway in Troms $\emptyset$, \\ 9037 Troms $\varnothing$, Norway \\ ${ }^{3}$ Department of Earth Science, University of Bergen, Postboks 7803, 5020 Bergen, Norway
}

Correspondence: Jean-Baptiste P. Koehl (jean-baptiste.koehl@uit.no)

Received: 13 August 2018 - Discussion started: 27 August 2018

Revised: 27 November 2018 - Accepted: 7 December 2018 - Published: 21 December 2018

\begin{abstract}
In the Devonian-Carboniferous, a rapid succession of clustered extensional and contractional tectonic events is thought to have affected sedimentary rocks in central Spitsbergen, Svalbard. These events include Caledonian post-orogenic extensional collapse associated with the formation of thick Early-Middle Devonian basins, Late Devonian-Mississippian Ellesmerian contraction, and Early-Middle Pennsylvanian rifting, which resulted in the deposition of thick sedimentary units in Carboniferous basins like the Billefjorden Trough. The clustering of these varied tectonic settings sometimes makes it difficult to resolve the tectono-sedimentary history of individual stratigraphic units. Notably, the context of deposition of Mississippian clastic and coal-bearing sedimentary rocks of the Billefjorden Group is still debated, especially in central Spitsbergen. We present field evidence (e.g., growth strata and slickensides) from the northern part of the Billefjorden Trough, in Odellfjellet, suggesting that tilted Mississippian sedimentary strata of the Billefjorden Group deposited during active (Late/latest?) Mississippian extension. WNW-ESEstriking basin-oblique faults showing Mississippian growth strata systematically die out upwards within Mississippian to lowermost Pennsylvanian strata, thus suggesting a period of widespread WNW-ESE-directed extension in the Mississippian and an episode of localized extension in EarlyMiddle Pennsylvanian times. In addition, the presence of abundant basin-oblique faults in basement rocks adjacent to the Billefjorden Trough suggests that the formation of Mississippian normal faults was partly controlled by reactivation of preexisting Neoproterozoic (Timanian?) basement-seated
\end{abstract}

fault zones. We propose that these preexisting faults reactivated as transverse or accommodation cross faults in or near the crest of transverse folds reflecting differential displacement along the Billefjorden Fault Zone. In Cenozoic times, a few margin-oblique faults (e.g., the Overgangshytta fault) may have mildly reactivated as oblique thrusts during transpression-contraction, but shallow-dipping, beddingparallel, duplex-shaped décollements in shales of the Billefjorden Group possibly prevented substantial movement along these faults.

\section{Introduction}

At the end of the Caledonian Orogeny in late Paleozoic times, Norway (Séranne et al., 1989; Osmundsen and Andersen, 2001; Gudlaugsson et al., 1998; Koehl et al., 2018a), Greenland (Hartz and Torsvik, 1997; Sartini-Rideout et al., 2006; Hallett et al., 2014; McClelland et al., 2016), and Svalbard (Manby and Lyberis, 1992; Braathen et al., 2018) were part of a large E-W trending intra-cratonic basin (Ziegler et al., 2002) that was subjected to a major episode of gravitational collapse, resulting in the formation of thick, Early to Middle Devonian sedimentary basins that evolved into rift basins in Late Devonian (?) to Carboniferous times (Fig. 1). In Spitsbergen, however, Late Devonian-Mississippian times recorded a short-lived period of contraction related to the Ellesmerian Orogeny, inverting Devonian collapse basins and associated basin-bounding faults (Piepjohn, 2000; Bergh et al., 2011; Piepjohn et al., 2015). Further transpression re- 
lated to the opening of the northeast Atlantic Ocean and the formation of a major fold-and-thrust belt in Cenozoic times complicates the study of Mississippian sedimentary rocks, making it difficult to identify and resolve Mississippian fault movements.

Although the sedimentology and stratigraphy of Mississippian sedimentary rocks are well studied in Spitsbergen (Gjelberg and Steel, 1981; Gjelberg, 1984; McCann and Dallmann, 1996; Maher Jr., 1996), Bjørnøya (Gjelberg, 1981; Gjelberg and Steel, 1983; Worsley et al., 2001) and the SW Barents Sea (Bugge et al., 1995; Larssen et al., 2002; Samuelsberg et al., 2003; Koehl et al., 2018a), little is known about the tectonic setting in which they were deposited, i.e., during Ellesmerian contraction-transpression, for example, in foreland basins (Piepjohn, 2000; Bergh et al., 2011; Piepjohn et al., 2015) or during a continuous episode of extensional collapse in spoon-shaped basins (e.g., Séranne et al., 1989; Osmundsen and Andersen, 2001; Koehl et al., 2018c) and/or during rifting (Gjelberg and Steel, 1981; Gjelberg, 1984) or during a period of tectonic quiescence (e.g., Johannessen and Steel, 1992; Braathen et al., 2011). Thus, the present local study has broad regional implications, especially regarding the geodynamic setting of Arctic regions in the Mississippian (contraction, extension, tectonic quiescence, transitional?), the architecture and geometry of the Barents Sea and west Spitsbergen margins (Mississippian basins?), and the distribution of Mississippian coal-bearing hydrocarbon source rock around Svalbard and in the Barents Sea.

Currently, in the Billefjorden Trough in central Spitsbergen (Braathen et al., 2011), Mississippian sedimentary rocks are believed to represent pre-rift sedimentary rocks deposited prior to the main phase of extension in the Pennsylvanian (Johannessen and Steel, 1992; Braathen et al., 2011). However, new field observations in Mississippian strata in Austfjorden, in the northern part of the Billefjorden Trough (Fig. 1), challenge this model. The present study provides new insights into the Mississippian tectonic history of central Spitsbergen, Svalbard, using field structural analysis of newly exposed Mississippian sedimentary deposits in Odellfjellet, Austfjorden (Fig. 1). These sedimentary rocks are mildly reworked by Cenozoic transpression and show preserved Mississippian primary faults and offsets, thus representing an excellent opportunity to resolve the tectonic history of this period. We emphasize the control of NW-SEstriking faults, like the Overgangshytta fault, on the deposition of Mississippian-Lower Pennsylvanian sedimentary strata and use adjacent and/or overlying Lower-Late Pennsylvanian sedimentary rocks as a comparison. We compare basement-seated NW-SE-striking faults in central Spitsbergen with similar faults in northern Norway, which possibly formed during to the late Neoproterozoic Timanian Orogeny (Roberts and Siedlecka, 2002; Roberts and Olovyanishnikov, 2004). Finally, we discuss potential controlling factors that may have influenced Mississippian faulting.

\section{Geological setting}

\subsection{Precambrian geology}

The study area, the Billefjorden Trough, is located at the boundary of two major structural domains, the northwestern and eastern terranes of Svalbard (Harland and Wright, 1979; Ohta et al., 1989; Labrousse et al., 2008), previously named the Nordfjorden and Ny-Friesland blocks, respectively (Cutbill and Challinor, 1965; Harland et al., 1974). East of the trough, the Ny-Friesland block is composed of basement rocks with well-developed, variably dipping, $\mathrm{N}-\mathrm{S}$-trending foliation, dominated by biotite-amphibolite gneisses of the Eskolabreen Complex (Balashov et al., 1993; Johansson and Gee, 1999) and Meso- to Neoproterozoic metasedimentary rocks of the Smutsbreen and Polhem formations (Harland et al., 1966). These rocks are involved in a large-scale, N-Strending, gently north-plunging fold structure, the Atomfjella Antiform (Witt-Nilsson et al., 1998). In addition, Paleoproterozoic granitic and granodioritic basement gneisses (Harland et al., 1974) crop out in the hanging wall of the Balliolbreen Fault and in the footwall of the Odellfjellet Fault, two major segments of a regional east- to ENE-dipping fault complex, known as the Billefjorden Fault Zone (BFZ; Harland et al., 1974; McCann and Dallmann, 1996; Braathen et al., 2011; Fig. 1).

\subsection{Late Paleozoic post-Caledonian basins and faults}

\subsubsection{Devonian sedimentary basins}

Post-Caledonian "Old Red" collapse basins formed along inverted Caledonian thrusts in the Early to Late Devonian and are bounded by major N-S- to NNW-SSE-striking faults (Harland et al., 1974; Manby and Lyberis, 1992; Manby et al., 1994). Large portions ( $>6 \mathrm{~km}$ thick) of these basins are preserved west of a west-dipping segment of the BFZ, although they were probably deposited east of the fault as well (McCann and Dallmann, 1996). Devonian collapse sediments were possibly reworked by contraction related to the Late Devonian-Mississippian Svalbardian phase (McCann, 2000; Piepjohn, 2000; Bergh et al., 2011; Piepjohn et al., 2015). Notably, in Billefjorden and Austfjorden (Fig. 1), positive tectonic inversion of the Balliolbreen segment of the BFZ resulted in overthrusting and the juxtaposition of Paleoproterozoic, granitic, and granodioritic basement gneisses to the east with Devonian clastic sedimentary deposits to the west (Fig. 1; McCann, 2000). However, this short-lived episode of contraction is challenged by new evidence of basement exhumation, possibly as core complexes along inverted Caledonian shear zones in Early to Late Devonian times in northwestern Spitsbergen (Braathen et al., 2018), in Early Devonian to Mississippian times in the SW Barents Sea (Klein and Steltenpohl, 1999; Klein et al., 1999; Steltenpohl et al., 2011; Koehl et al., 2018a), and in the Late Devonian- 


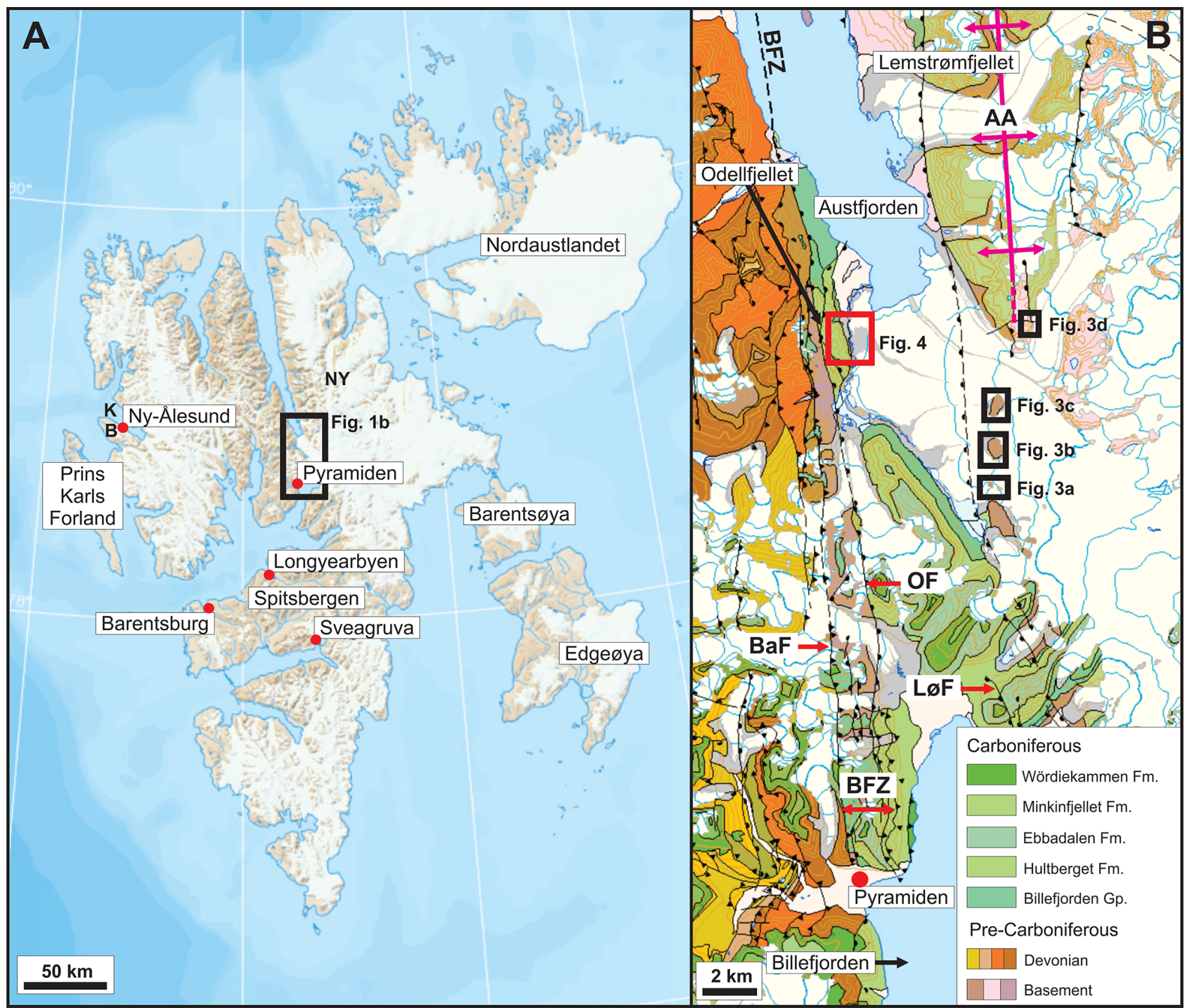

Figure 1. (a) Topography map of Spitsbergen, Svalbard. Modified from https://toposvalbard.npolar.no; last access: 18 December 2018. Abbreviations are as follows: B - Brøggerhalvøya; K - Kongsfjorden; NY - Ny-Friesland. (b) Geological map of the Billefjorden-Austfjorden area, the location of which is shown in (a). The location of studied outcrops is shown by a red frame. The red double arrow shows the width of the Billefjorden Fault Zone (BFZ) at Pyramiden, in Billefjorden. This fault is composed of two main segments: the Balliolbreen Fault and the Odellfjellet Fault. The Atomfjella Antiform is shown in pink. Areas shaded in white represent glaciers. The map is from svalbardkartet.npolar.no. Abbreviations are as follows: AA - Atomfjella Antiform; BaF - Balliolbreen Fault; LøF - Løvehovden Fault; OF Odellfjellet Fault.

Mississippian in northeastern Greenland (Sartini-Rideout et al., 2006; Hallett et al., 2014; McClelland et al., 2016).

\subsubsection{Carboniferous sedimentary basins}

During post-Caledonian, Carboniferous ENE-WSWdirected extension/sinistral transtension, multiple sedimentary troughs formed throughout the Svalbard archipelago, e.g., the Billefjorden, Lomfjorden, St Jonsfjorden, and Inner Hornsund troughs (Maher Jr., 1996; McCann and Dallmann, 1996), while major sedimentary basins, such as the Sørkapp, Nordkapp, and Hammerfest basins, developed in the Barents Sea (Gabrielsen et al., 1990; Gudlaugsson et al., 1998; Anell et al., 2016; Koehl et al., 2018a). These basins and troughs were filled with thick Carboniferous sediments deposited along (reactivated) high-angle normal faults, like the east-dipping Balliolbreen and Odellfjellet segments of the BFZ in central Spitsbergen (Harland et al., 1974; McCann and Dallmann, 1996).

Mississippian sedimentary strata are up to $2.5 \mathrm{~km}$ in cumulative thickness and are easily recognizable at outcrop scale because they commonly comprise coal seams and 
coaly shales interbedded with dominant clastic deposits, both in the Barents Sea (Bugge et al., 1995; Larssen et al., 2002; Samuelsberg et al., 2003), on Bjørnøya (Gjelberg and Steel, 1983; Gjelberg, 1984), and in Spitsbergen (Cutbill and Challinor, 1965; Cutbill et al., 1976; Gjelberg, 1981, 1984; Gjelberg and Steel, 1981). In central Spitsbergen (e.g., in Billefjorden), preserved Mississippian strata are relatively thin $(<300 \mathrm{~m}$; Cutbill et al., 1976) and are divided into two formations: the Hørbyebreen Formation composed of the Triungen and Hoelbreen members, and the Mumien Formation including the Sporehøgda and Birger Johnsonfjellet members (Fig. 2). The Hoelbreen and Birger Johnsonfjellet members show abundant, characteristic coal seams and coaly shales, whereas the Triungen and Sporehøgda members are dominantly composed of clastic sedimentary deposits (Cutbill and Challinor, 1965; Cutbill et al., 1976; Gjelberg and Steel, 1981; Gjelberg, 1984; Fig. 2).

Mississippian sedimentary rocks of the Billefjorden Group are generally believed to represent pre-rift units (Johannessen and Steel, 1992; Braathen et al., 2011), though an early syn-rift origin is considered possible (Steel and Worsley, 1984; Nøttvedt et al., 1993; McCann and Dallmann, 1996). The pre-rift interpretation is largely based on the presence of Mississippian rocks on both sides of the BFZ. Moreover, Mississippian sedimentary strata display NW-plunging folds (e.g., in western Spitsbergen), suggesting that they might have (partly) deposited during west-directed thrusting related to the Svalbardian phase (Bergh et al., 2011) of the Late Devonian-Mississippian Ellesmerian Orogeny (McCann, 2000; Piepjohn, 2000). During this contractional event, the BFZ might have acted as a transpressional fault, possibly accommodating left-lateral displacement $>200 \mathrm{~km}$ (Harland et al., 1974). In addition, contraction-related uplift may be responsible for extensive erosion of Mississippian rocks. Thus, it is commonly difficult to compare sedimentary successions in the footwall and hanging wall of faults and to identify potential growth strata (McCann and Dallmann, 1996).

Pennsylvanian sedimentary rocks in central Spitsbergen represent the thickest preserved sedimentary deposits recorded in the Billefjorden Trough. These are divided into five formations belonging to the Gipsdalen Group (Fig. 2). First, the late Serpukhovian Hultberget Formation is composed of characteristic red and subsidiary grey sandstones, conglomerates, and shales (Cutbill and Challinor, 1965; Cutbill et al., 1976; Johannessen, 1980; Gjelberg and Steel, 1981; Johannessen and Steel, 1992; Fig. 2). Second, the Bashkirian Ebbadalen Formation is made of highly variable lithologies, including interbedded grey-yellow sandstones and grey-green shales (Ebbaelva Member), and red and yellow sandstones and conglomerates interbedded with red shales (Odellfjellet Member) interfingering with gypsumanhydrite and dark limestones and dolomites (Trikolorfjellet Member; Holliday and Cutbill, 1972; Johannessen, 1980; Johannessen and Steel, 1992; Braathen et al., 2011;
Fig. 2). Third, the Moscovian Minkinfjellet Formation is dominated by limestone and dolomite with minor evaporites (Carronelva and Terrierfjellet members) and carbonate karst breccias (Fortet Member; McWhae, 1953; Cutbill and Challinor, 1965; Lønøy, 1995; Fig. 2). Fourth and fifth, the Wördiekammen and Gipshuken formations mainly consist of dolomite and limestone interbedded with evaporites and crosscut by dissolution breccias in the latter (Gee et al., 1952; Cutbill and Challinor, 1965).

By contrast to the pre-rift origin inferred for Mississippian sedimentary units, Pennsylvanian rocks of the Hultberget, Ebbadalen, and Minkinfjellet formations are thought to represent, respectively, the early, main, and late synrift sedimentation episodes (Prosser, 1993) or the "initiation", "interaction and linkage", and "through-going fault" stages (Gawthorpe and Leeder, 2000, their Fig. 3) in the Billefjorden Trough (Johannessen and Steel, 1992; Braathen et al., 2011). Pennsylvanian syn-rift sedimentation was accompanied by significant kilometer-scale downthrowing to the east along the BFZ and tilting of SW-dipping Carboniferous normal faults and related fault-propagation folds into a subvertical/east-dipping position in the eastern part of the Billefjorden Trough (e.g., the Løvehovden Fault; Maher Jr. and Braathen, 2011; Braathen et al., 2011). Middle Pennsylvanian-Cisuralian sedimentary strata of the Wördiekammen and Gipshuken formations are largely accepted as late syn-rift to post-rift sedimentary units (Braathen et al., 2011), in other words as part of the through-going fault stage of Gawthorpe and Leeder (2000). In Odellfjellet (Austfjorden; Fig. 1), newly exposed strata investigated in the present contribution crop out near cliffs of tens (hundreds?) of meters thick Pennsylvanian sedimentary strata of the Hultberget, Ebbadalen, and Minkinfjellet formations (Johannessen and Steel, 1992; Lamar and Douglass, 1995).

\subsection{Cenozoic fold and thrust belt}

Apart from a few minor tectonic episodes, e.g., in the Permian-Triassic (Worsley and Mørk, 1978; Mørk et al., 1982; Steel and Worsley, 1984; Osmundsen et al., 2014) and potentially in the Cretaceous (Nemec et al., 1988; Prestholm and Walderhaug, 2000; Onderdonk and Midtkandal, 2010), the Svalbard Archipelago is believed to have remained relatively quiet tectonically from the end of the Pennsylvanian to the end of the Mesozoic. In mid-Cenozoic times, ENE-WSW-oriented contractionaltranspressional deformation related to continental breakup and subsequent opening of the northeast Atlantic Ocean formed subhorizontal NW- to NNW-trending folds (Bergh et al., 1997; Bergh and Grogan, 2003) and inverted major normal faults, resulting in the formation of the West Spitsbergen fold-and-thrust belt (Harland, 1969; Lowell, 1972; Harland et al., 1974; Haremo et al., 1990; Dallmann et al., 1993; Dißmann and Grewing, 1997). Cenozoic dextral transpression and contraction reactivated preexisting, margin- 


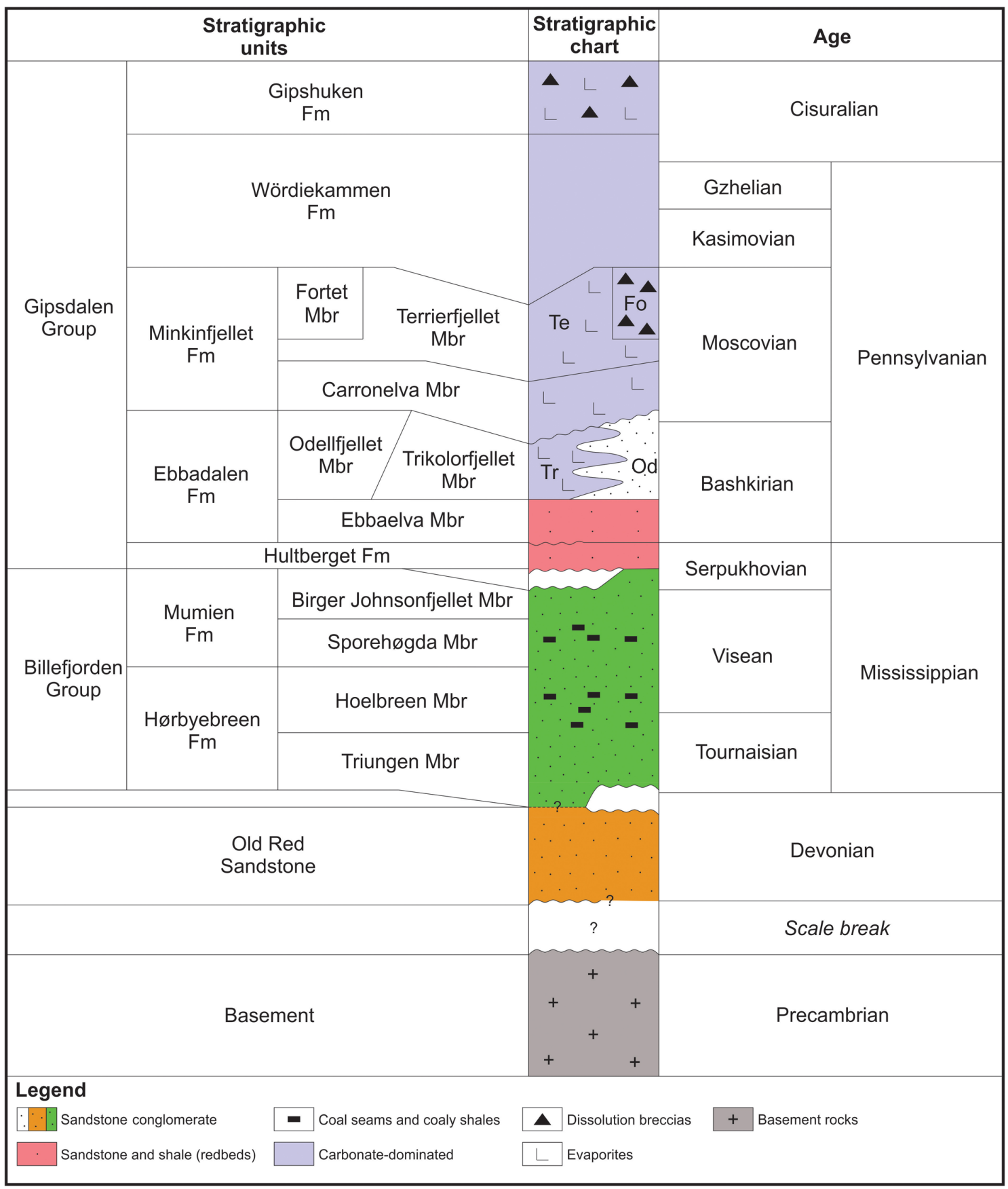

Figure 2. Lithostratigraphic chart of late Paleozoic sedimentary rocks in central Spitsbergen. The chart is based on descriptions by Gee et al. (1952), McWhae (1953), Playford (1962), Cutbill and Challionor (1965), Holliday and Cutbill (1972), Cutbill et al. (1976), Johannessen (1980), Gjelberg (1981, 1984), Gjelberg and Steel (1981), Johannessen and Steel (1992), Lønøy (1995), Dallmann (1999), Braathen et al. (2011), and Scheibner et al. (2015).

parallel, N-S-trending Caledonian and margin-oblique NWSE- to NNW-SSE-trending Svalbardian (Ellesmerian) folds and thrusts (Bergh et al., 1997; Blinova et al., 2012, 2013) and inverted Devonian-Carboniferous normal faults such as the BFZ, making fault offsets difficult to resolve.

\section{Methods}

The present work is a compilation of satellite images from https://toposvalbard.npolar.no (last access: 18 December 2018), covering areas in the eastern part of the Billefjorden Trough (Fig. 3), and of field structural observations 


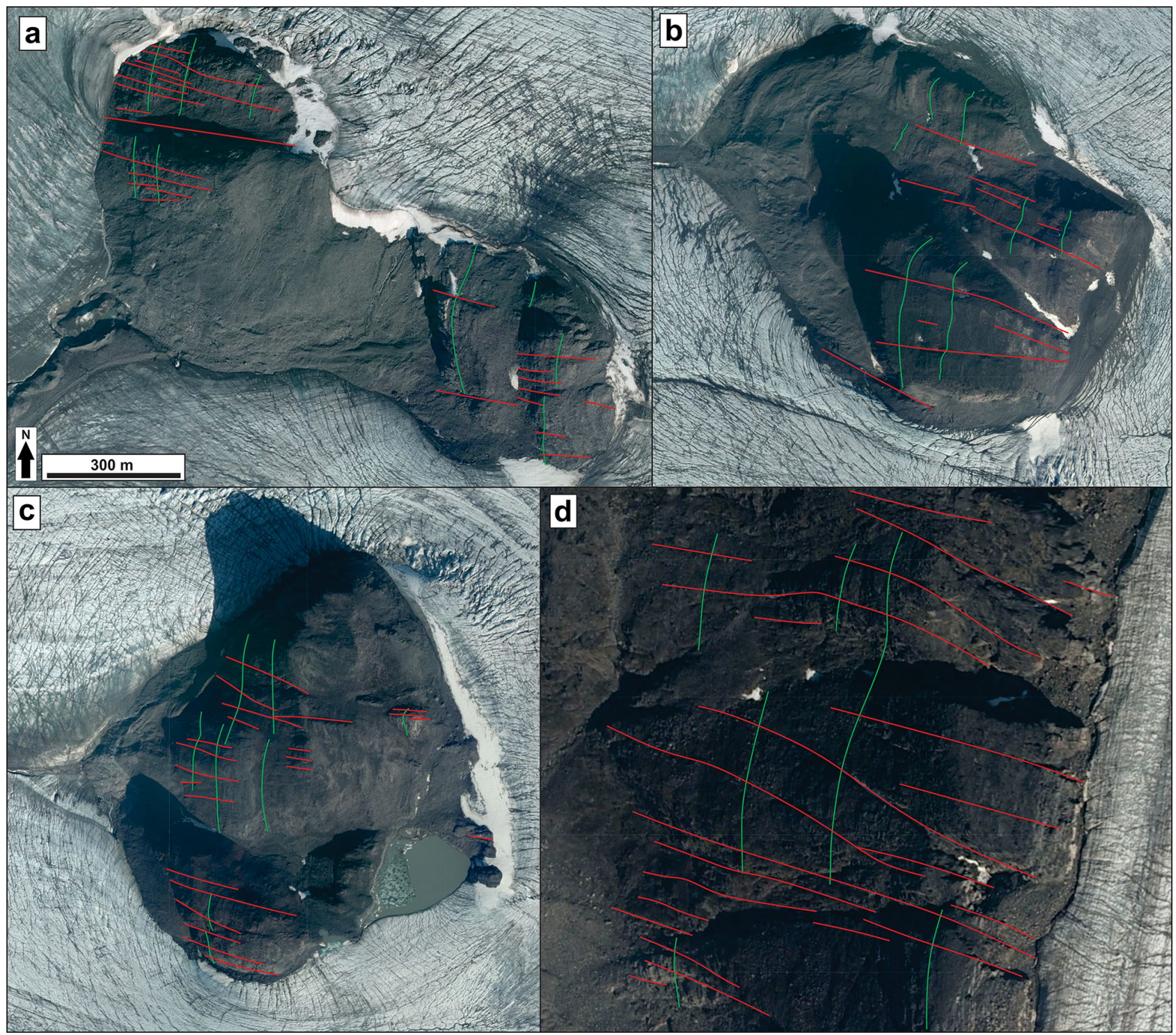

Figure 3. Satellite images from https://toposvalbard.npolar.no showing arcuate to rectilinear lineaments representing the prominent NS-trending gneissic foliation of the Atomfjella Antiform and WNW-ESE-trending lineaments interpreted as steep Neoproterozoic brittle faults in basement exposures east and southeast of Odellfjellet in (a) Framstakken, (b) Heclastakken, (c) Furystakken, and (d) southernmost Sederholmfjellet. Locations are displayed as black frames in Fig. 1b. North and scale are common to all four satellite images and are displayed in (a).

in Carboniferous sedimentary rocks in Odellfjellet (Fig. 1) collected during a field excursion in summer 2016 (Fig. 4). Structural data are plotted in lower-hemisphere, equal-area Schmidt stereonets as great circles. Satellite images of exposed basement rocks were used to identify brittle faults in exposed but difficultly accessible Proterozoic basement rocks adjacent to Carboniferous sedimentary deposits in the Billefjorden Trough. In addition, fault surfaces and escarpments in the field were tied to map-view lineaments on satellite images that matched their trend and location (Fig. 4). Critical factors used in the interpretation of geological features on satellite images in inaccessible areas include existing literature (e.g., N-S-trending gneissic foliation in basement rocks east and southeast of the field area was evidenced by multiple works, including notably Harland et al., 1966, and Witt-Nilsson et al., 1998), the geological database at https: //svalbardkartet.npolar.no (last access: 18 December 2018), and similarities with fault-related escarpments tied to actual brittle faults in the field area (Fig. 4). Glacial features were segregated from ductile and brittle structures and fabrics using satellite images and scientific literature on recent and past glacial flow. Satellite images used in the present study are from 2011 and have a horizontal resolution of $40 \mathrm{~cm}$. 


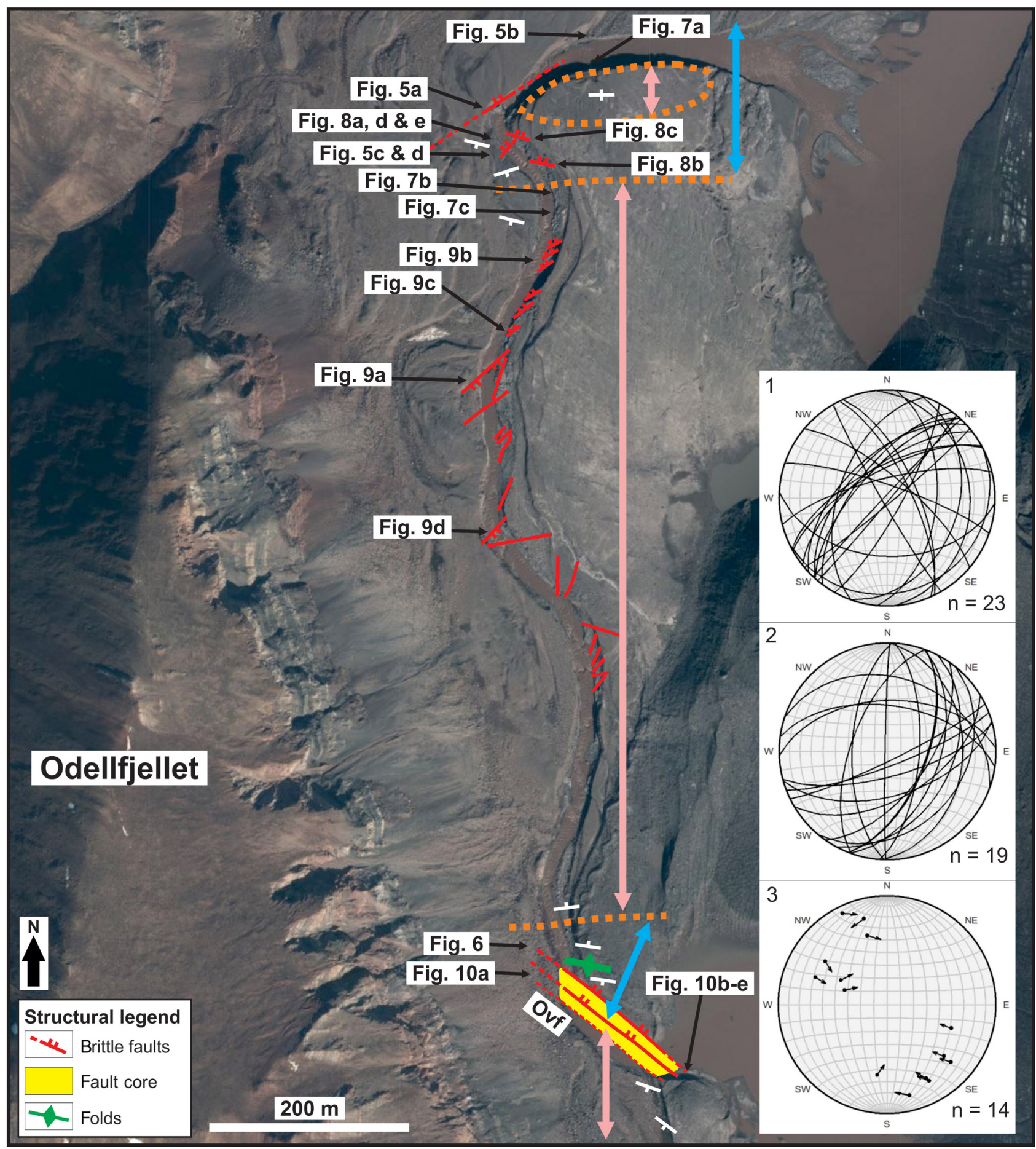

Figure 4. Satellite image from https://toposvalbard.npolar.no showing the study area in Odellfjellet. The studied outcrops are located along a riverbed and consist of sedimentary rocks of the Billefjorden Group (blue double arrows) and Hultberget Formation (pink double arrows) crosscut by brittle faults (e.g., the Overgangshytta fault - Ovf). The riverbed runs subparallel to mountain cliff outcrops made of sedimentary strata of the Hultberget, Ebbadalen, and Minkinfjellet formations (Odellfjellet). Dotted orange lines represent stratigraphic boundaries between the Billefjorden Group and Hultberget Formation. Bedding surface measurements are shown as white lines. The stereoplots show (1) great circle fracture surfaces within rocks of the Billefjorden Group and (2) Hultberget Formation and (3) poles and vectors of slickenside lineations along brittle faults crosscutting rocks of the Billefjorden Group and Hultberget Formation. Location is shown by a red frame in Fig. 1b. 


\section{Results}

\subsection{Basement rocks}

East and southeast of the investigated outcrops by a riverbed in Odellfjellet (Fig. 1), Mesoproterozoic to earliest Neoproterozoic basement rocks crop out and display a welldeveloped N-S-trending gneissic foliation (Harland et al., 1966; Balashov et al., 1993; Witt-Nilsson et al., 1998; Johansson and Gee, 1999). This prominent ductile fabric is visible on satellite images where it defines series of clustered, (sub-) parallel, linear to arcuate lineaments following the topography of ridges exposed within Mittag-Lefflerbreen, e.g., Framstakken (Fig. 3a), Heclastakken (Fig. 3b), and Furystakken (Fig. 3c), and on mountain flanks, e.g., the southernmost tip of Sederholmfjellet (Fig. 3d). In these outcrops, basement rocks are glaciated (Marks and Wysokinski, 1986) and glacial lineations and features are easily differentiated from basement ductile fabrics and correlated with ongoing ice flow (Fig. 3; Marks and Wysokinski, 1986).

Discrete, steep, WNW-ESE-trending escarpments occur and trend oblique (sub-orthogonal) to the prominent $\mathrm{N}-$ S-trending foliation in Mesoproterozoic to Neoproterozoic basement rocks (Fig. 3; Harland et al., 1966; Balashov et al., 1993; Witt-Nilsson et al., 1998; Johansson and Gee, 1999). Further, these escarpments are parallel to steeply dipping strike-slip to normal brittle faults that crosscut the Atomfjella Antiform in northern Ny-Friesland, e.g., the Mosseldalen Fault (Witt-Nilsson et al., 1998). Thus, we interpret the abundant WNW-ESE-trending escarpments in basement rocks in southernmost Sederholmfjellet and in basement ridges in Mittag-Lefflerbreen as representing steep, inherited, Neoproterozoic to early/mid-Paleozoic WNW-ESE-striking brittle faults. This is supported by outcrop occurrences of similarly striking basin-oblique brittle faults in Ebbadalen (in Billefjorden; Christophersen, 2015) and Biscahalvøya (in northwestern Spitsbergen; Gee, 1972; Labrousse et al., 2008), which crosscut Mesoproterozoic to earliest Neoproterozoic basement rocks and terminate below unconformably overlying Devonian-Carboniferous sedimentary deposits.

\subsection{Sedimentary rocks}

\subsubsection{Dark grey sandstones and coaly shales}

In Odellfjellet (Figs. 1 and 4), we evidenced the presence of a several tens of meter thick succession made of meterthick beds of grey sandstones and dark coaly shales showing a gentle $\left(10-30^{\circ}\right)$ south-to-southwestward dip (Fig. 5a). The lower part of this succession crops out at the river mouth and is dominated by interbedded, meter-thick beds of coalbearing shale and grey sandstone (Fig. 5a). Coal-bearing shales showed sparse plant fossils, including Stigmaria ficoides (Fig. 5b; Playford, 1962; Birkenmayer and Turnau, 1962). The upper part of the succession crops out hundreds of meters south- and southwestwards along the riverbed. There, the succession also includes beds of grey claystone with iron nodules (Fig. 5c) and soil profiles with polygonal fractures (Fig. 5d). One kilometer southwards along the riverbed, the upper part of the succession of grey sandstone-coaly shale crops out again and is interbedded with thin decimeter- to meter-thick beds of yellow sandstone in the hanging wall of a major fault, the Overgangshytta fault. At this location, the succession forms a 10-20 m wide, E-W- to WNW-ESEtrending, open and upright anticline (Fig. 6).

Based on previous descriptions of the Billefjorden Group and Hultberget Formation in Billefjorden (Cutbill et al., 1976; Gjelberg, 1984), the grey sandstone and coaly shale sedimentary strata observed at the river mouth and in the hanging wall of the Overgangshytta fault may either belong to the upper part of the Billefjorden Group or represent the base of the Hultberget Formation. Iron nodules similar to those found in the upper part of the grey sandstone-coaly shale succession (Fig. 5c) have not been described in the lower part of the Hultberget Formation and are rather typical of the upper part of this Formation (Cutbill et al., 1976). By contrast, iron nodules are fairly common within the upper part of the Sporehøgda and Birger Johnsonfjellet members of the Mississippian Mumien Formation (Cutbill et al., 1976; Gjelberg, 1984; Fig. 2). In addition, the presence of soil profiles (Fig. 5d) and Stigmaria ficoides (Fig. 5b), a plant fossil abundantly found in the Billefjorden Group (Playford, 1962; Birkenmayer and Turnau, 1962; Gjelberg, 1984), respectively, near the top and base of the described outcrops rather suggests that the grey sandstone and coaly shale strata in Odellfjellet are part of the Billefjorden Group.

\subsubsection{Red sandstones and shales}

At the river mouth, tilted beds of grey sandstones and coalbearing shales are in angular unconformity contact with flat-lying decimeter- to meter-thick beds of red to yellow sandstones partly covered by Quaternary glacial deposits (Fig. 7a). Hundreds of meters southwards along the riverbed, grey sandstones and dark coaly shales are interbedded with thin, tens of centimeter-thick beds of yellow sandstone (Fig. 7b), the proportion of which gradually increases southwards. Farther south, coaly shales eventually disappear and are replaced by abundant meter-thick red sandstone and shale interbedded with subsidiary decimeter-thick grey to yellow sandstone (Fig. 7c). Based on the typical red coloration of the dominant sandstone and shale beds and on the presence of thin beds of yellow sandstone and subsidiary grey sandstone (Cutbill et al., 1976; Gjelberg, 1984), we propose that the red-bed sedimentary succession described herein is part of the Hultberget Formation (Fig. 2). 


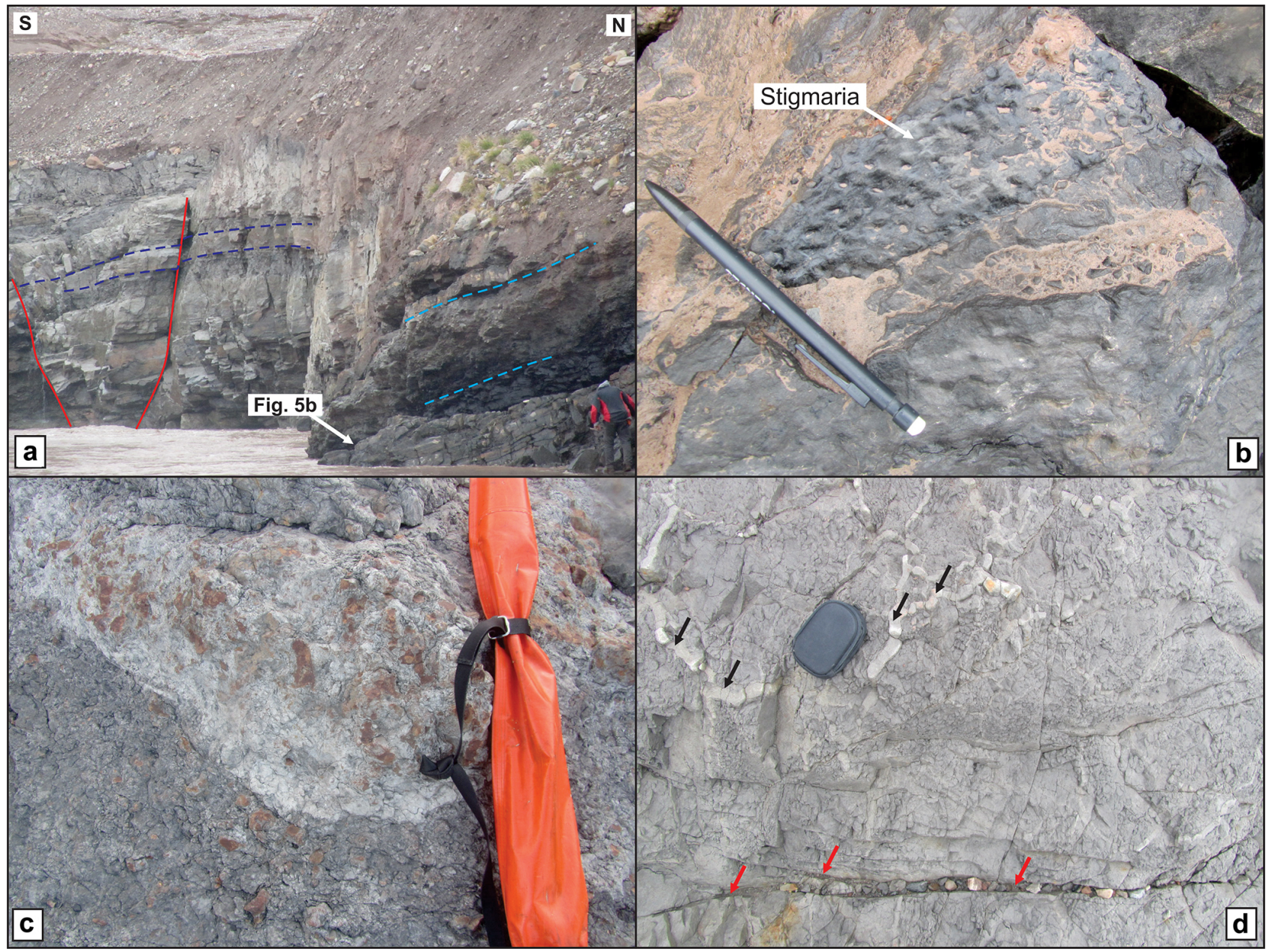

Figure 5. Outcrop photographs showing (a) southwestwardly tilted sedimentary rocks of the Billefjorden Group consisting of interbedded coal-bearing shales and grey sandstone in the lower part (light blue) and interbedded coaly shales, grey sandstone, and grey claystone with iron nodules in the upper part (dark blue). Person for scale in the lower right corner. (b) Stigmaria ficoides in the lower part of the Billefjorden Group succession. Location shown in (a). (c) Grey claystone with abundant iron nodules in the upper part of the Billefjorden Group succession. Orange rifle cover as scale (approximately $1.20 \mathrm{~m}$ long). (d) Soil features in grey claystone crosscut by fractures (red arrows) and polygonal fractures (black arrows) in the upper part of the Billefjorden Group succession. Camera cover $(15 \times 10 \mathrm{~cm})$ as scale. Outcrop locations shown in Fig. 4.

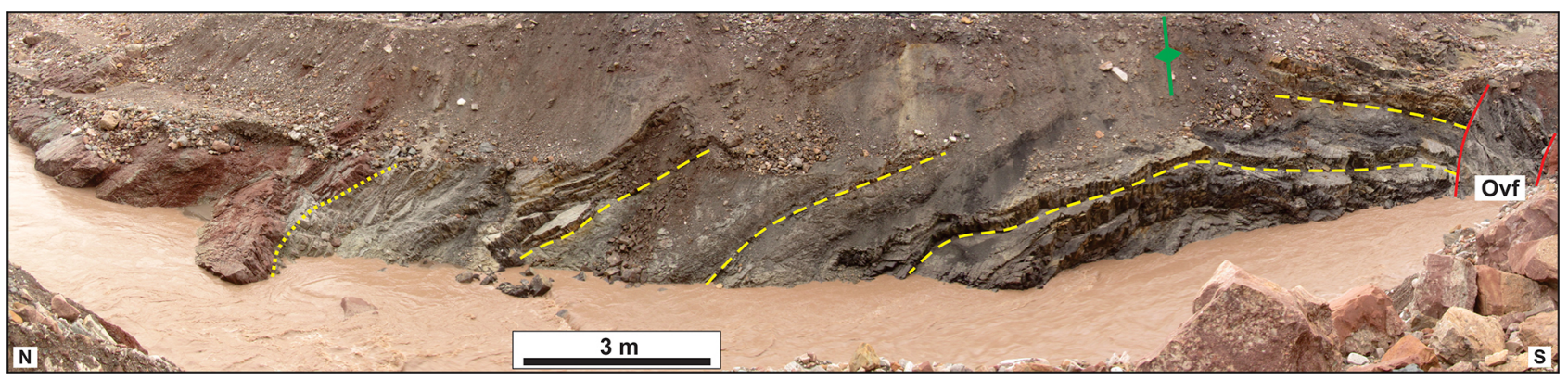

Figure 6. Eastward view of folded sedimentary strata (bedding in dashed yellow) forming an E-W- to WNW-ESE-trending, open, upright anticline (green) in the hanging wall of the Overgangshytta fault (red; Ovf), along the southern portion of the riverbed (Fig. 4). Note the boundary (conformity?) between grey sandstones and coaly shales of the Billefjorden Group and red sandstones and shales of the Hultberget Formation in dotted yellow. See Fig. 4 for location. 


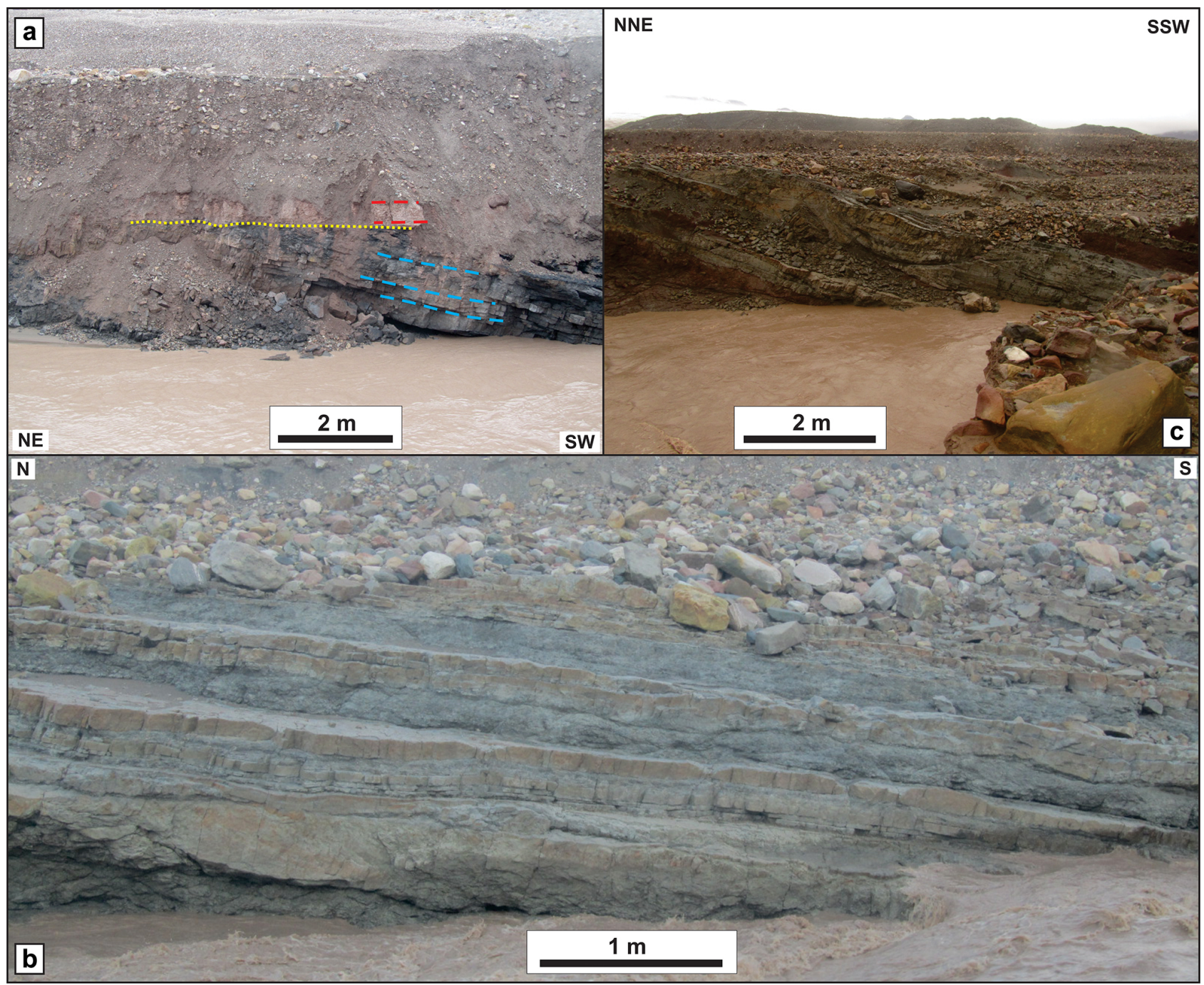

Figure 7. (a) Outcrop photographs showing southwestwardly tilted sandstone- and coaly-shale-rich beds of the Billefjorden Group (dashed blue) unconformably (unconformity in dotted yellow) overlain by flat-lying (dashed red) red beds of the Hultberget Formation. Outcrop located at the northern end of the riverbed (see Fig. 4). (b) Grey sandstone and shales interbedded with thin beds of yellow sandstones (transitional between Billefjorden Group and Hultberget Formation?). Outcrop location in Fig. 4. (c) Red shale interbedded with grey and yellow sandstone characteristic of the Hultberget Formation in Odellfjellet, Austfjorden. See Fig. 4 for outcrop location.

\subsection{Brittle faults}

\subsubsection{Faults within the Billefjorden Group}

In Odellfjellet (Figs. 1 and 4), sedimentary rocks of the Billefjorden Group are crosscut by steep NE-SW- to ENE-WSW, NW-SE- to WNW-ESE-, and subsidiary NNE-SSW- to N-S-striking faults (Fig. 4). Brittle faults display abundant, centimeter- to decimeter-thick lenses of fine-grained, lightcolored, non-cohesive fault rock (i.e., fault gouge; Woodcock and Mort, 2008; Fig. 8a). Slickensides (grooves) along these faults indicate dominant normal dip-slip and subordinate normal oblique-slip movements (Fig. 4) and offsets are generally decimeter to meter scale (Fig. 8). WNW-ESE- to NW-
SE-striking faults generally die out within grey sandstones and coaly shales of the Billefjorden Group and often display thickened sandstone beds in the hanging wall, which do not appear to continue into the faults' footwall (Fig. 8b-c). Based on the dominant normal sense of shear of these faults, we argue that thickened sedimentary strata in the hanging wall represent potential tens of centimeter thick growth strata reflecting syn-tectonic sedimentation. Notably, Fig. 8c shows that, in places, interpreted syn-tectonic growth strata along NNE-dipping faults are composed of two discrete sedimentary units, including proximal sandy wedges and distal prograding to sheet-like sand bodies eroded upwards, which are separated from each other by an angular unconformity. 


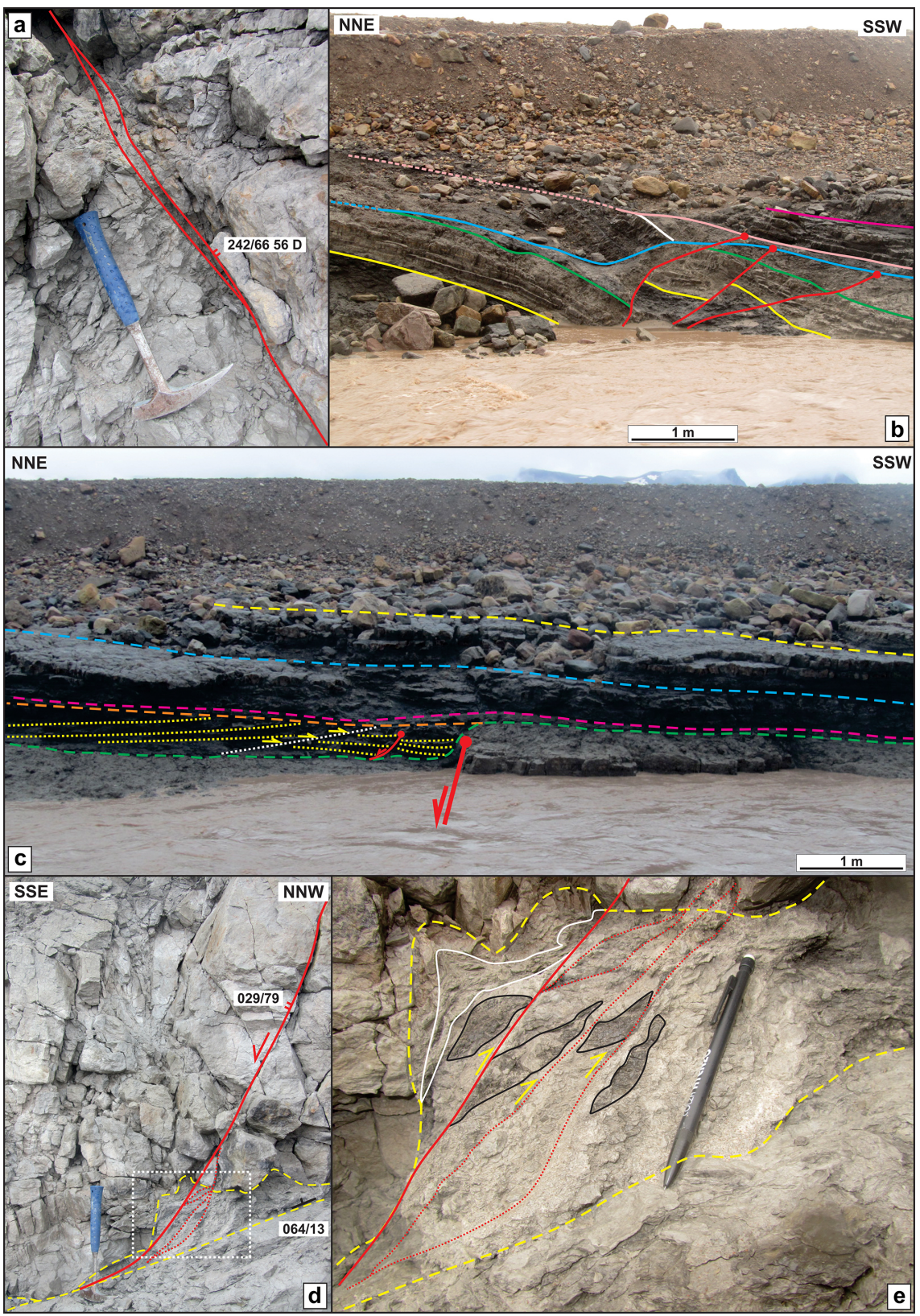

Figure 8. Outcrop photographs showing (a) centimeter-decimeter-thick lenses of light-colored fault gouge along a brittle fault truncating grey sandstones of the Billefjorden Group. Figure location in Fig. 4. (b) NNE-dipping normal faults showing meter-scale down-NNE movement and potential growth strata (between the green and blue markers). The faults crosscut sandstones and shales of the Billefjorden Group in which they die out upwards. See Fig. 4 for location. (c) Potential fault-growth strata made of dark sandstone (between the green and orange markers) in the hanging wall of a NNE-dipping brittle fault with decimeter-meter-scale normal displacement. The fault dies out upwards within sedimentary strata of the Billefjorden Group. The interpreted syn-tectonic growth strata are composed of two sedimentary packages, including a proximal sandy wedge thickening towards the fault and a distal prograding to sheet-like sand-rich body onlapping (divergent onlap; yellow arrows) the proximal wedge. The two packages are separated by an angular unconformity (dotted white line) and are both eroded upwards (orange dashed line). Yellow dotted lines represent intra-bed surfaces. Outcrop location in Fig. 4. (d) Outcrop photograph showing a high-angle brittle normal fault (red line) in grey sandstone of the Billefjorden Group flattening and soling into a gently southdipping shale-dominated bed (dashed yellow lines) displaying significant thickness variations. The dotted white frame shows the location of (e), and white boxes show structural measurements (fault surface in red and bedding surface in black). See Fig. 4 for outcrop location. (e) Zoomed-in photograph showing thickening of the shale-dominated bed (dashed yellow lines) in the footwall of the flattening normal fault (red line), including fine-grained (meso- to ultra-) cataclasite and preserved fragments of coaly shale host rock (black lines) seemingly offset in a reverse top-northwest fashion by small-scale faults that form a duplex-shaped structure (dashed red lines). In the hanging wall, the shale-dominated bed significantly thins and is preserved as a lens of partly squeezed shale (white line) and cataclasite. Location shown by a dotted white frame in (d). 
In places, high-angle $\left(>70^{\circ}\right)$ brittle faults appear to flatten and sole into shale-dominated beds of the Billefjorden Group, forming duplex-like geometries that incorporate lenses of squeezed shale and dominantly fine-grained cohesive fault rock (i.e., meso- to ultra-cataclasite; Woodcock and Mort, 2008) with clasts of partially preserved coaly shale, as well as possible shallow-dipping, bedding-parallel décollements (Fig. 8d-e). In cross section, these flattening brittle faults display a normal sense of shear (red line in Fig. 8de), while smaller faults within duplex-like structures show minor centimeter-scale reverse offsets of host-rock clasts (dashed red lines in Fig. 8d-e). We tentatively interpret these as Carboniferous normal faults and duplexes soling downwards into shale-dominated décollements, which were subsequently partly reactivated as reverse faults, possibly during Cenozoic transpression.

\subsubsection{Faults within the Hultberget Formation}

Sedimentary rocks of the Hultberget Formation are crosscut by steep NNE-SSW- to N-S-, NE-SW- to ENE-WSW-, and subsidiary low-angle WNW-ESE-striking faults (Fig. 4). Fault cores include centimeter- to decimeter-thick lenses of light-colored fault gouge (Fig. 9a). Displacement along these faults is in the order of a few decimeters to $1-2 \mathrm{~m}$, as shown by normal offsets of red and grey sedimentary beds (Fig. 9bd). A major difference between faults crosscutting the Billefjorden Group and those truncating red and grey strata of the Hultberget Formation is that we did not identify any growth strata in the latter, therefore suggesting that movement along brittle faults crosscutting the Hultberget Formation occurred after sediment deposition.

\subsubsection{The Overgangshytta fault}

The southernmost outcrops along the riverbed are crosscut by a major NNE-dipping fault that we name the Overgangshytta fault (Figs. 4 and 10a). In the hanging wall, this fault is characterized by a decametric/mesoscale anticline incorporating beds of grey sandstones and coaly shales of the Billefjorden Group interbedded with thin beds of yellow sandstone more typical of the Hultberget Formation (Fig. 6). The footwall of the fault is dominated by red sandstones and shales interbedded with grey to yellow sandstones (Fig. 10a). These rocks are similar to those of the Hultberget Formation farther north along the riverbed (Fig. 7c) and to red Devonian sandstones also observed in the area, west of the BFZ (McCann and Dallmann, 1996). The 2-3 m thick fault core comprises steeply SSW-tilted strata (Fig. 10a) crosscut by abundant fractures comprising centimeter- to decimeter-scale lenses of yellow (Fig. 10b) and light-colored fault gouges (Fig. 10c). The fault shows slickenside lineations indicating dip-slip normal movements (Fig. 10d). The Overgangshytta fault was not observed in adjacent cliffs to the WNW, where sedimentary strata of the Hultberget, Ebbadalen, and Minkin- fjellet formations crop out, possibly suggesting that the fault dies out laterally and/or vertically (Fig. 10e and Supplement).

\section{Discussion}

\subsection{Origin of the Overgangshytta fault}

The red sandstones and shales interbedded with grey to yellow sandstones in the footwall of the Overgangshytta fault (Fig. 10a, d and e) are similar to kilometer-thick Devonian sedimentary deposits observed west of the BFZ in adjacent onshore areas in André Land (Manby and Lyberis, 1992), and their presence in the footwall of the Overgangshytta fault may indicate hundreds of meter- to kilometer-scale, downNNE, normal displacement along this fault. However, such Devonian deposits have never been observed east of the BFZ and are believed to have been eroded or never deposited (Harland et al., 1974). Thus, sedimentary strata in the footwall of the Overgangshytta fault (Fig. 10a and e) are more likely to represent uppermost Mississippian-lowermost Pennsylvanian strata of the Hultberget Formation, analogous to those observed in the hanging wall of the fault (Fig. 7a-b). Isopach maps from Cutbill et al. (1976) suggest that the Hultberget Formation is no thicker than $80 \mathrm{~m}$ in Odellfjellet, and, therefore, the presence of sedimentary strata of the Hultberget Formation on both sides of the Overgangshytta fault may indicate vertical displacement comprised between a few meters and $80 \mathrm{~m}$ along the fault. This is supported by quantitative studies on the width of fault cores (e.g., Forslund and Gudmundsson, 1992; Childs et al., 2009; Bastesen and Braathen, 2010; Johannessen, 2017), which indicate that faults with 2$3 \mathrm{~m}$ wide core zones (like the Overgangshytta fault; Fig. 10a) generally accommodate vertical displacement ranging from a few meters to several hundreds of meters.

The Overgangshytta fault was not observed in adjacent cliff outcrops (Figs. 4, 10e, and Supplement), which suggests that the fault dies out laterally approximately $300 \mathrm{~m}$ to the west-northwest and/or upwards within the Hultberget Formation. However, the width of the fault core (2-3 m), the suggested displacement along the fault (a few meters to several tens of meters), and the intensity of deformation in the hanging wall of the fault along the riverbed (Figs. 6 and 10a-c) do not support a nearby lateral termination of the fault. Notably, quantitative studies discussing potential relationships between fault length and displacement show that a fault like the Overgangshytta fault is likely to be several hundred to a few thousand meters long (Watterson, 1986; Nicol et al., 1995; Schlische et al., 1996; Gudmundsson, 2000; Kolyukhin and Torabi, 2012).

By contrast, northwards, along the riverbed, NNE-dipping faults striking parallel to the Overgangshytta fault die out upwards in coal-bearing sedimentary rocks of the Billefjorden Group (Fig. 8b-c). We therefore propose that the Overgangshytta fault also dies out upwards within the uppermost 


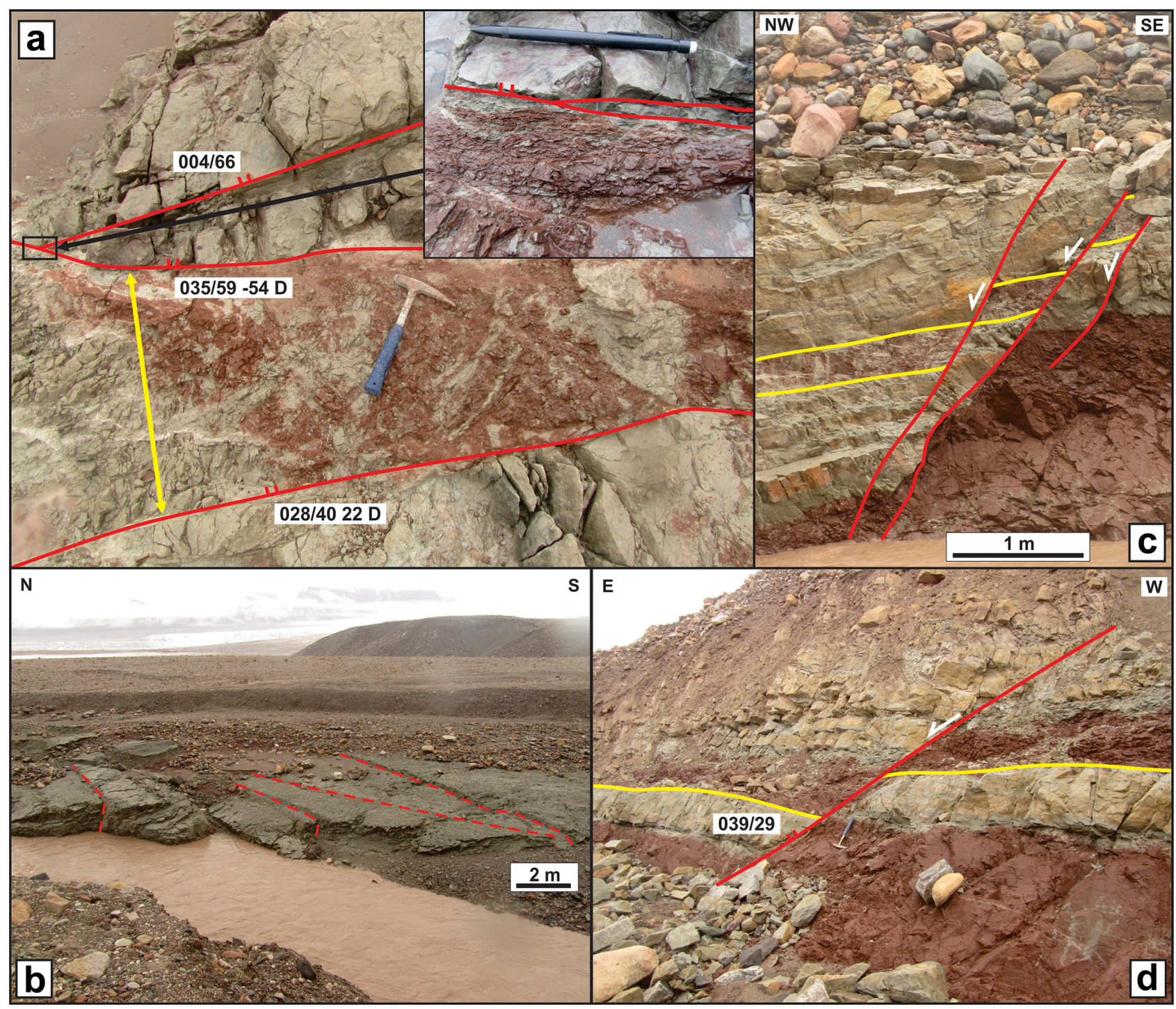

Figure 9. Outcrop photographs along the southern half of the riverbed (Fig. 4) showing (a) meter-scale fault core (yellow arrow) along a SW-dipping fault comprising light-colored and reddish fault gouge derived, respectively, from adjacent grey sandstone and red shales of the Hultberget Formation. The upper right inset shows shattered sedimentary rocks truncated by numerous subparallel brittle shears along the main fault surface. (b) Decimeter-scale fault scarps related to decimeter-meter-scale down-northwest and down-west normal movements along NE-SW- and N-S-striking brittle faults in the Hultberget Formation. (c) Decimeter-scale down-NW normal offset (yellow lines) along a NE-SW-striking brittle fault crosscutting red shale and grey sandstone of the Hultberget Formation. (d) Meter-scale down-SE offset (yellow lines) along a low-angle normal fault truncating the Hultberget Formation. Figure locations in Fig. 4.

Mississippian-Lower Pennsylvanian strata of the Hultberget or Ebbadalen Formation. Such an upwards dying-out geometry was also observed for similarly striking, steep, SWto SSW-dipping faults in Billefjorden, the Kampesteindalen Fault, and Ebbabreen faults. The former dies out within the Ebbadalen Formation and juxtaposes sedimentary strata of the Hultberget Formation in the footwall with rocks of the Ebbadalen Formation in the hanging wall (Braathen et al., 2011; Aleksandra A. Smyrak-Sikora, personal communication, 2016), whereas the latter downthrow thickened Mississippian rocks of the Billefjorden Group to the southwest and die out upwards within the Hultberget Formation (McCann and Dallmann, 1996). Thus, the steep and upwards dyingout geometry of the Overgangshytta fault (Fig. 10e) together with slicken grooves indicating normal dip-slip movement (Fig. 10d) suggests that this fault formed as an extensional normal fault in the Mississippian to earliest Pennsylvanian.

East and southeast of the studied outcrops in Odellfjellet (Fig. 1), satellite images show numerous WNW-ESEtrending escarpments in Paleoproterozoic to earliest Neoproterozoic basement rocks in Sederholmfjellet and MittagLefflerbreen (Fig. 3), which we interpreted as steep brittle 


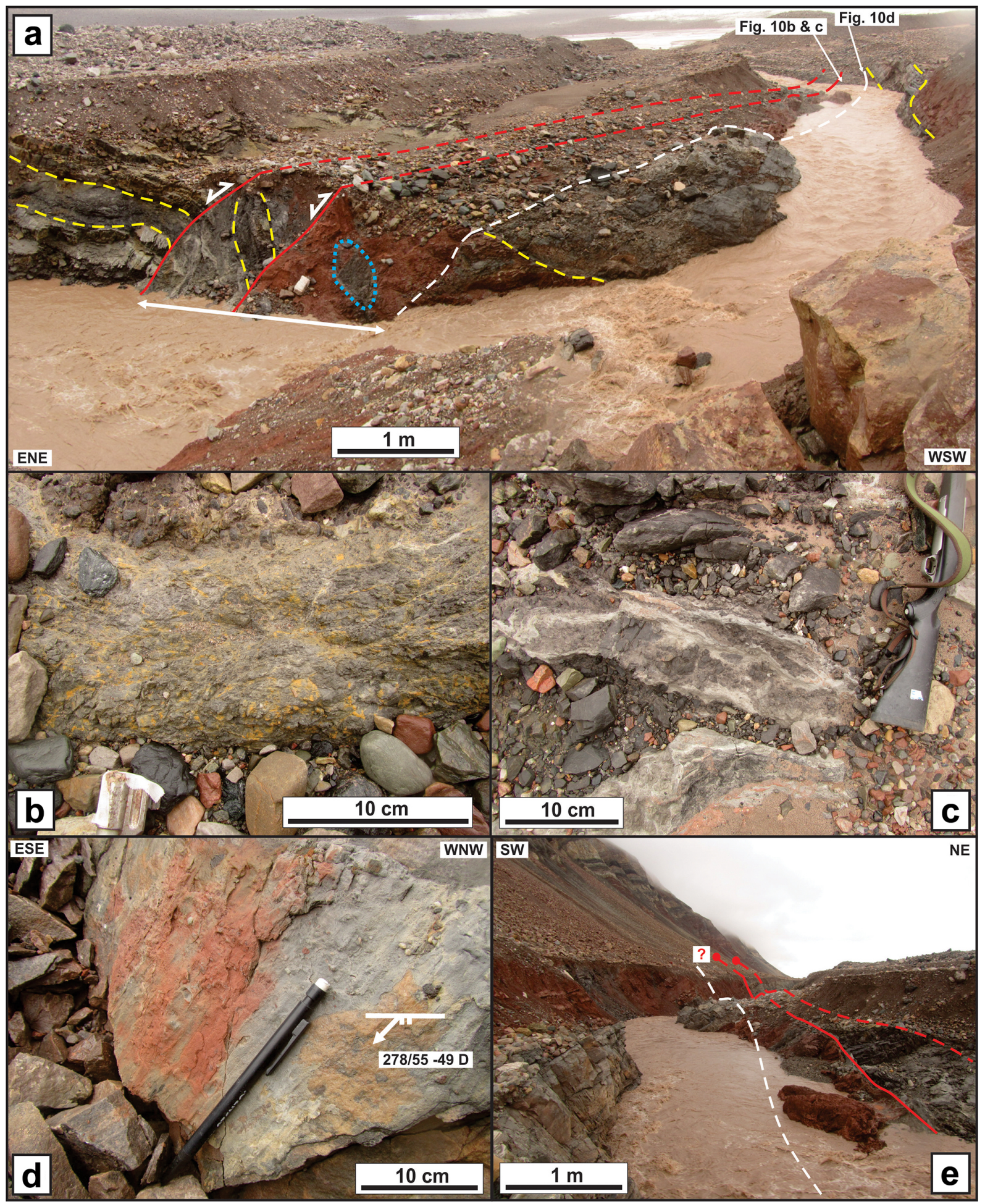

Figure 10. Eastward view of the Overgangshytta fault in the southern portion of the study area. Figure locations in Fig. 4. Panels (a) 2-3 m wide core (subhorizontal white arrow shows the width of the core) of the Overgangshytta fault (red) incorporating meter-size lenses of host rock (dotted blue). Note the potential meter-scale reverse offset, possibly drag fold in the hanging wall, and highly tilted (bedding in dashed yellow) character of coaly shales and grey sandstones of the Billefjorden Group across the fault. (b) Decimeter-scale light-colored and (c) approximately $10 \mathrm{~cm}$ wide yellowish lenses of fault gouge within the Overgangshytta fault core. (d) Slicken grooves and asperities indicating normal dip-slip movement within the Overgangshytta fault core. See Fig. 10a for location. (e) Northwestward view of the Overgangshytta fault and adjacent cliff outcrops made of sedimentary rocks of the Hultberget, Ebbadalen, and Minkinfjellet formations suggesting that the fault dies out vertically and/or laterally. The fault core is limited by the dashed white and dashed red lines and is approximately $3 \mathrm{~m}$ wide. 
faults based on their similarities with fault-related lineaments in the field area (Fig. 4) and their obliquity to the dominant N-S-trending ductile fabrics and structures (Harland et al., 1966; Balashov et al., 1993; Witt-Nilsson et al., 1998; Johansson and Gee, 1999). Although not always reconstructed in paleo-tectonic reconstructions, in the early Neoproterozoic, the position of Svalbard was probably close to the Timanian margin of northern Baltica prior to the opening of the Asgard Sea and Iapetus Ocean/Ægir Sea (Torsvik et al., 1996; Cawood et al., 2001, 2010; Cawood and Pisarevsky, 2017) and prior to the Timanian Orogeny in the late Neoproterozoic (Roberts and Siedlecka, 2002; Roberts and Olovyanishnikov, 2004). In northern Baltica, similar, steep, abundant, WNW-ESE-striking, margin-oblique (i.e., oblique to the Atlantic margin) brittle faults were mapped on the Varanger Peninsula (Siedlecka and Siedlecki, 1967; Siedlecka, 1975; Siedlecka, 1980) and Magerøya (Koehl, 2018; Koehl et al., 2018c) in northern Norway, and these represent fault segments of a major, inherited, Neoproterozoic subvertical fault, the Trollfjorden-Komagelva Fault Zone, which formed during the Timanian Orogeny and is thought to have accommodated hundreds of kilometers of lateral displacement (Rice, 2013). This fault experienced multiple episodes of reactivation and was last reactivated under transtension; shortly before it was intruded by Mississippian (Visean; Lippard and Prestvik, 1997) dolerite dykes that seal the fault (Roberts et al., 1991; Nasuti et al., 2015). Hence, we propose that the WNW-ESE-trending fault-related escarpments observed in Paleoproterozoic to earliest Neoproterozoic basement rocks in Sederholmfjellet and Mittag-Lefflerbreen (Fig. 3) correspond to inherited Neoproterozoic (Timanian?) strike-slip faults. Possible inherited Timanian fabrics also exist in southern Spitsbergen and include steep WNW-ESE- to NW-SEstriking Neoproterozoic faults and shear zones that show affinities with the Timanides of northern Norway (Mazur et al., 2009; Majka et al., 2010), thus supporting our interpretation. Moreover, a recent seismic study suggests a Timanian origin for the WNW-ESE-trending Olga Basin in the northern Barents Sea (Klitzke et al., 2018a, b). We propose that steep basement-seated margin-oblique faults in central Spitsbergen were partly reactivated as normal faults during postCaledonian extension and may have localized the formation of Mississippian-earliest Pennsylvanian basin-oblique WNW-ESE-striking normal faults like the Overgangshytta fault in Odellfjellet. Such interpretation accounts both for the strike-slip (inherited?) and normal (post-Caledonian reactivation?) shear senses inferred for WNW-ESE-striking faults in northern Ny-Friesland (Witt-Nilsson et al., 1998).

In the hanging wall of the Overgangshytta fault, the anticline involving sedimentary rocks of the Hultberget Formation and Billefjorden Group (Fig. 6) may represent a normal fault-related fold (Schlische, 1995), e.g., a rollover anticline formed as a response to large extensional displacement along a listric fault, or a growth anticline formed during the propagation of the fault into overlying sedimentary rocks of the Billefjorden Group (?) and Hultberget Formation. An origin as a rollover anticline is incompatible with the inferred geometry of the Overgangshytta fault at depth, as this fault may have formed along (a) preexisting steepsubvertical inherited Neoproterozoic fault(s) and is unlikely to be listric. This is supported by satellite images showing numerous steep WNW-ESE-trending fault-related escarpments in exposed Paleoproterozoic to earliest Neoproterozoic basement rocks southeast (Mittag-Lefflerbreen; Fig. 3a-c) and east of Odellfjellet (Sederholmfjellet; Fig. 3d), which most likely continue below the studied outcrops of Carboniferous sedimentary rocks, and by field mapping of abundant steep WNW-ESE-striking faults in northern Ny-Friesland (WittNilsson et al., 1998). Conversely, a formation as a potential growth anticline is compatible with the inferred steep geometry of the Overgangshytta fault at depth. The Overgangshytta fault may have propagated upwards from an existing, steep, inherited, Neoproterozoic, basement-seated fault during post-Caledonian Mississippian to earliest Pennsylvanian extension. Such a mechanism was recently proposed to explain the geometry of the N-S-striking Løvehovden Fault in Billefjorden (Maher Jr. and Braathen, 2011). Another possibility is that the Overgangshytta anticline formed as a faultbend anticline (Rotevatn and Jackson, 2014, their Fig. 4b) during downward linkage of the Overgangshytta fault with a preexisting basement-seated WNW-ESE-striking fault during (Late/latest?) Mississippian-Pennsylvanian extension.

Alternatively, the observed anticline (Fig. 6) formed much later, during Cenozoic contraction-dextral transpression associated with the formation of the West Spitsbergen foldand-thrust belt (Harland, 1969; Lowell, 1972; Bergh et al., 1997; Leever et al., 2011), thus potentially reflecting topSSW thrusting. The Overgangshytta fault actually strikes subparallel to most NW-SE-striking Cenozoic thrust faults mapped onshore western Spitsbergen (Braathen and Bergh, 1995; Bergh et al., 1997, 2000) and in nearshore fjords in central Spitsbergen (Bergh et al., 1997; Blinova et al., 2012, 2013). Considering its obliquity with the main N-S- to NNW-SSE-trending axis of the West Spitsbergen fold-andthrust belt, the Overgangshytta fault might have reactivated as a minor oblique thrust fault, potentially accommodating a few meters to several tens of meters of reverse displacement during a stage of dextral transpression. This is consistent with minor (centimeter- to decimeter-scale) reverse offsets in meter-scale duplexes localized within bedding-parallel décollement levels in shale-dominated beds of the Billefjorden Group in Odellfjellet (Fig. 8d-e), which might represent minor inversion of Carboniferous normal faults during Cenozoic transpression (Fig. 8). Moreover, analog field studies along fault segments of the San Andreas Fault in Indio Hills (Koehl et al., 2017; Jean-Baptiste P. Koehl et al., unpublished data, 2017) and Mecca Hills in California (Bergh et al., 2014, 2018) show that minor thrust faults developed oblique to major strike-slip faults during dextral transpression, and the relative orientation of these oblique thrusts compared to the San 
Andreas Fault matches that of the Overgangshytta fault compared to the BFZ in Svalbard (Figs. 1 and 4).

Despite having potentially reactivated as a minor oblique thrust during Cenozoic dextral transpression, the Overgangshytta fault did not propagate into adjacent cliff outcrops made of Pennsylvanian deposits (Fig. 10e and Supplement). We argue that this may be ascribed to the observed steep and inferred subvertical geometries of the Overgangshytta fault at the surface and at depth, respectively, which were most likely not suitable to accommodate significant reverse displacement (as observed for small-scale duplexes; Fig. 8d-e). As a result, the fault was only mildly reactivated with little or no upwards propagation, and adjacent sedimentary rocks of the Hultberget Formation and Billefjorden Group were gently folded (Fig. 6). Alternatively or in addition, low-angle bedding-parallel décollements in shaly beds of the Billefjorden Group might have inhibited Cenozoic deformation, partly decoupling deformation between basement and postMississippian sedimentary rocks, thus explaining the lack of inversion structures in the studied outcrops. This resulted in a mild inversion of the Overgangshytta fault (Fig. 10a) and duplex-like geometries and minor reverse faulting in Mississippian shales (Fig. 8d-e). It is noteworthy that the Overgangshytta anticline might as well be the result of combined Carboniferous normal fault-related folding and Cenozoic inversion.

\subsection{Mississippian extension}

\subsubsection{Mississippian growth strata along basin-oblique faults}

Evidence in favor of Mississippian syn-sedimentary extensional brittle faulting include (i) fault slickenside lineations yielding a dominant normal dip-slip and subsidiary normal oblique-slip sense of shear (Figs. 4 and 10d) and (ii) sedimentary beds thickened by several tens of centimeters interpreted as fault-growth strata in the hanging wall of NNEdipping brittle faults crosscutting coal-bearing sedimentary rocks of the Billefjorden Group (Fig. 8b and c). Although it was not possible to measure the strike of the faults showing Mississippian growth strata in the hanging wall, they obviously trend subparallel to the NNE-dipping Overgangshytta fault (Figs. 4 and 8b-c). Importantly, in Fig. 8c, the interpreted syn-tectonic unit in the hanging wall of the NNEdipping fault displays a proximal sandy wedge and a distal, onlapping (divergent onlap), prograding to sheet-like sand body. On the one hand, based on the thickening of the wedge towards the fault and on intra-bedding surfaces (dotted yellow lines in Fig. 8c), the proximal sand-rich wedge is believed to reflect a period of normal faulting with rapid accommodation creation (Osmundsen et al., 2014, their Fig. 12a). Mississippian normal faulting in Austfjorden is also supported by dominant WNW-ESE- to NW-SE-trending paleocurrent data from the Sporehøgda Member in Lemstrømfjel- let (Fig. 1), on the eastern shore of Austfjorden (Gjelberg, 1981; his Fig. 4.5), suggesting that sedimentary strata of the Sporehøgda Member, both in Odellfjellet and Lemstrømfjellet, might have deposited along active WNW-ESE-striking faults.

On the other hand, the geometry of the distal prograding to sheet-like sand body in Fig. 8c suggests a period of slow accommodation creation (Osmundsen et al., 2014, their Fig. 12c and d), potentially reflecting upward propagation of the fault as a blind fault, as shown in Gawthorpe et al. (1997, their Fig. 3a) and as inferred for the Løvehovden Fault farther south, in Billefjorden (Maher Jr. and Braathen, 2011), and thus indicating decreasing fault activity along WNWESE-striking faults during the deposition (of the upper part?) of the Sporehøgda Member (Mumien Formation, Billefjorden Group) in Odellfjellet. Unlike the Overgangshytta fault, minor WNW-ESE-striking faults displaying growth strata in cross section do not extend upwards into red beds of the Hultberget Formation (Fig. 8b-c). This suggests that extensional faulting along WNW-ESE-striking faults ceased prior to the late Serpukhovian (latest Mississippian), which is consistent with the tectono-sedimentary interpretation of intra-growthstrata packages along these faults that indicate decreasing extension (Fig. 8c). However, this does not necessarily imply that regional extension ended in the Mississippian. The rheological contrast between interbedded meter-thick shaly beds and sandstone units of the Billefjorden Group may have been high enough to at least partly decouple extensional deformation between basement rocks and post-Mississippian sedimentary units. Evidence for such decoupling in Odellfjellet are found as shallow-dipping, bedding-parallel, duplexshaped décollements in (coaly) shale-dominated beds. We believe that the (at least) several tens of meter-thick sedimentary rocks of the Billefjorden Group were thick enough to decouple extension and potentially prevent further (Pennsylvanian) movements along margin-oblique WNW-ESE-striking faults (Fig. 8c-e). Such decoupling effects of interbedded shaly beds and sandstone units on (normal) faults is wellknown from previous studies (e.g., Wilkins and Gross, 2002).

Nevertheless, the minimum (Late/latest?) Mississippian age of WNW-ESE-striking faults in Odellfjellet is consistent with Mississippian (Visean) ${ }^{40} \mathrm{Ar}-{ }^{39} \mathrm{Ar}$ ages obtained on dolerite dykes intruded during extension/transtension and sealing segments of the Trollfjorden-Komagelva Fault Zone in northern Norway (Roberts et al., 1991; Lippard and Prestvik, 1997). It is also consistent with Late DevonianMississippian K-Ar ages obtained for fault gouge in northern Norway (Davids et al., 2013; Torgersen et al., 2014; Koehl et al., 2018b) and northeast Greenland (Rotevatn et al., 2018). This also possibly suggests that the Overgangshytta fault initially died out within Mississippian strata of the Billefjorden Group and, later on, propagated into overlying sedimentary deposits of the Hultberget Formation, potentially during a mild episode of inversion of the fault during Cenozoic contraction-transpression. As proposed for the Over- 
gangshytta fault, it is probable that most WNW-ESE-striking normal faults described in the present study formed along reactivated basement-seated Neoproterozoic fabrics (Fig. 3).

By contrast, although showing meter-scale normal offsets and slickenside lineations indicating a normal sense of shear (Figs. 4 and 9), N-S- and NE-SW-striking faults observed in Mississippian-lowermost Pennsylvanian strata of the Billefjorden Group and Hultberget Formation along the riverbed in Odellfjellet (Figs. 8a and 9b-d) did not display evidence of growth strata. Hence, the timing of formation of these faults remains uncertain. Nevertheless, knowing that the study area (Odellfjellet; Figs. 1 and 4) and, conceivably, most areas in central Spitsbergen were subjected to tectonic extension in the (Late/latest?) Mississippian (Figs. 8b-c and 10d), we propose that N-S- and NE-SW-striking faults (at least some of them) formed and acted simultaneously with WNW-ESEstriking faults during Mississippian extension, the only difference being that faults of the former two trends $(\mathrm{N}-\mathrm{S}$ and NE-SW) experienced further normal movement, possibly during (Early-Middle?) Pennsylvanian extension (Braathen et al., 2011), thus crosscutting rocks of the Hultberget Formation (Figs. 8a and 9b-d).

\subsubsection{Tilting of Mississippian strata of the Billefjorden Group}

In the north, sedimentary strata of the Billefjorden Group appear tilted and dip gently $\left(10-30^{\circ}\right)$ to the southwest, forming an angular unconformity with overlying flat-lying red beds of the Hultberget Formation (Fig. 7a). In the south, grey sandstones and coal-bearing sedimentary rocks of the Billefjorden Group are interbedded with and gradually replaced by conformably overlying clastic red beds of the Hultberget Formation (Figs. 6 and 7c). We argue that the observed angular unconformity in the north represents the distal portion of an uplifted, partly exposed rotated fault block and that conformably overlying beds of the Billefjorden Group and Hultberget Formation farther south correspond to proximal, hanging wall, syn-tectonic sedimentary strata deposited in a constantly or repeatedly flooded portion of an active fault block (Fig. 11). Consequently, the southwestward tilting of Mississippian sedimentary strata may reflect (Late/latest?) Mississippian extensional faulting along one or several NNE- to NE-dipping brittle faults, possibly the Overgangshytta fault and/or one or more similarly trending and dipping fault; see, e.g., Fig. $8 \mathrm{~b}$ and c. This thus supports the idea that extension initiated prior to the deposition of red-colored sedimentary strata of the Hultberget Formation. This interpretation is supported by similar observations in western Spitsbergen, where Mississippian coal-bearing sedimentary strata were proposed to have deposited in the hanging wall of an active SSW-dipping normal fault located in Kongsfjorden, forming a WNW-ESE-trending Mississippian basin, the Brøggerhalvøya trough (Bergh et al., 2000). The absence of Mississippian sedimentary strata northeast of Brøggerhalvøya was ascribed to uplift and erosion of the footwall of the fault in Kongsfjorden, and the fining upwards pattern recorded in the strata was suggested to represent a break in normal faulting activity near the end of the Mississippian (Fairchild, 1982).

Furthermore, in the Barents Sea, a major Late Mississippian (Serpukhovian) unconformity was described onshore Bjørnøya (Worsley et al., 2001) and on the Finnmark Platform (Bugge et al., 1995; Koehl et al., 2018a). This unconformity was correlated to a major eustatic sea-level fall at ca. $330 \mathrm{Ma}$ (Saunders and Ramsbottom, 1986; Haq and Schutter, 2008). This short-lived eustatic sea-level fall was followed by eustatic sea-level rise at ca. $325 \mathrm{Ma}$ (late Serpukhovian; Saunders and Ramsbottom, 1986; Haq and Schutter, 2008), coinciding with the deposition of the Hultberget Formation (Cutbill and Challinor, 1965). In Odellfjellet, the local absence of the Late Mississippian unconformity indicates that parts of central Spitsbergen remained flooded through the Serpukhovian, and these flooded areas appear to be located in the hanging wall of NNE-dipping faults (e.g., the Overgangshytta fault) that accommodated normal displacement in the (Late/latest?) Mississippian (Fig. 11). Thus, it is possible that areas where beds of the Hultberget Formation conformably overlie Mississippian strata of the Billefjorden Group, like in Billefjorden (central Spitsbergen; Cutbill et al., 1976) and Ditlovtoppen (eastern Spitsbergen; Scheibner et al., 2015), represent proximal portions of hanging walls (i.e., located near the fault) that were down-faulted during active normal faulting in the (Late/latest?) Mississippian.

Alternatively, the tilting of Mississippian strata in Odellfjellet might originate from west-directed Late DevonianMississippian (Ellesmerian) thrusting and/or ENE-WSWoriented Cenozoic transpression. However, Late DevonianMississippian transpression does not reconcile the interbedded character of the Hultberget Formation and Billefjorden Group, which conformably overlie one another in the south (Figs. 6, and 7b-c), and Cenozoic transpression would have resulted in the folding of the unconformity between the Billefjorden Group and Hultberget Formation in the north. Another explanation might be along-strike variation in displacement magnitude along the BFZ during the deposition of sedimentary strata of the Billefjorden Group, resulting in socalled "transverse folds" (Schlische, 1995). However, on the Finnmark Platform in the SW Barents Sea, Mississippian strata appear tilted along brittle normal faults and are partially eroded in distal portions of hanging walls (e.g., Koehl et al., 2018a, their Fig. 6a). Thus, we favor an interpretation related to down-NNE normal faulting for the observed southwestwards tilting of Mississippian sedimentary strata in Odellfjellet (Fig. 11).

\subsubsection{Switch from widespread to localized extension}

Our observations in Odellfjellet show that basin-oblique, WNW-ESE- to NW-SE-striking normal faults were active 


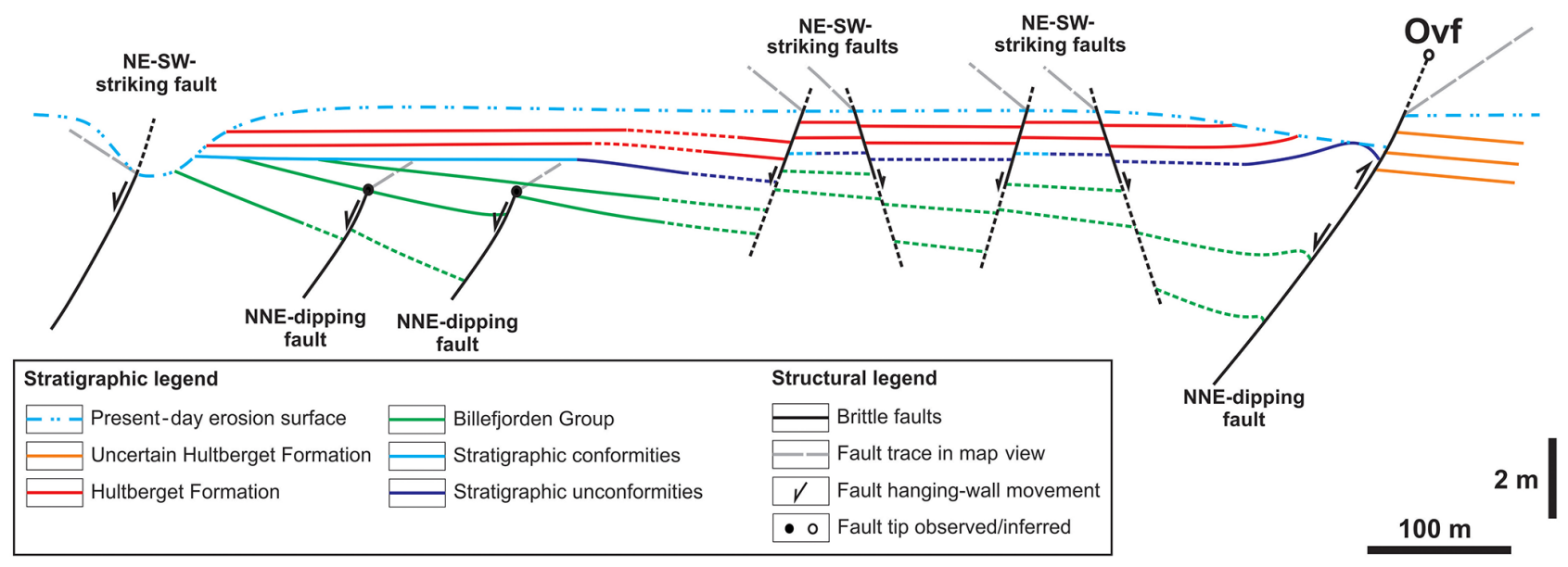

Figure 11. Approximately $1 \mathrm{~km}$ long schematic N-S-oriented cross section of the studied outcrops in Odellfjellet. The section summarizes observations made along the riverbed and includes upwards dying-out NNE-dipping normal faults with Mississippian growth strata, abundant N-S- and NE-SW-striking normal faults with decimeter-meter-scale offsets, and the Overgangshytta fault (Ovf), a potential Mississippian NNE-dipping normal fault formed along steep, inherited, basement-seated, Neoproterozoic fabrics. The anticline in the hanging wall of the Overgangshytta fault suggests that the fault was inverted as a thrust during Cenozoic transpression. Note the southward change from unconformity (light blue) to conformity (dark blue) between sedimentary strata of the Billefjorden Group and Hultberget Formation.

in (until?) the (Late/latest?) Mississippian (Fig. 8b-c). Similarly, in Birger Johnsonfjellet (central Spitsbergen), N-Sstriking faults showing growth strata with syn-depositional tilting die out upwards within Mississippian deposits of the Billefjorden Group (McCann and Dallmann, 1996), thus suggesting that at least some $\mathrm{N}-\mathrm{S}$-striking faults were active during Mississippian extension. Thus, we propose that central Spitsbergen was subjected to widespread Mississippian extension distributed along numerous faults of varied trends, including margin-oblique WNW-ESE- to NW-SE(Figs. 8b-c and 10a) and margin-parallel N-S-striking faults (McCann and Dallmann, 1996) and, conceivably, NE-SWstriking faults, thus possibly representing the rift initiation phase as detailed in Gawthorpe and Leeder (2000).

Margin-oblique faults systematically die out upwards within Mississippian (to lowermost Pennsylvanian) strata in Odellfjellet (Fig. 8b-c), Billefjorden (e.g., Ebbabreen and Kampesteindalen faults; McCann and Dallmann, 1996; Braathen et al., 2011; Aleksandra A. Smyrak-Sikora, personal communication, 2016), and Bjørnøya (e.g., Russleva Fault; Braathen et al., 1999; Koehl, 2018b). In addition, inherited margin-oblique faults in northern Norway were dated to have been last active in the Mississippian (e.g., the TrollfjordenKomagelva Fault Zone; Lippard and Prestvik, 1997). By contrast, only a few margin-parallel (N-S-striking) faults die out within Mississippian sedimentary deposits in central Spitsbergen (McCann and Dallmann, 1996), while most of these (e.g., BFZ; Harland et al., 1974; Braathen et al., 2011) and NE-SW-striking faults (Figs. 8a and 9b-d) cut through Pennsylvanian sedimentary rocks, suggesting that they remained active through the Early-Middle Pennsylvanian. We therefore propose that central Spitsbergen was subjected to an episode of continuous (Late/latest?) Mississippian-Middle Pennsylvanian extension during which normal displacement progressively localized along fewer fault trends $(\mathrm{N}-\mathrm{S}$ and NE-SW; interaction and linkage phase of Gawthorpe and Leeder, 2000), possibly using shallow-dipping, beddingparallel décollements in (coaly) shale-dominated beds of the Billefjorden Group (Fig. 8d-e) to decouple margin-oblique WNW-ESE-striking faults. Eventually, extension localized along a few major faults, such as the BFZ (through-going fault phase of Gawthorpe and Leeder, 2000), before ultimately ceasing in the Middle-Late Pennsylvanian.

This is similar to what was observed in the southwesternmost Nordkapp basin and on the Finnmark Platform in the SW Barents Sea (Koehl et al., 2018a), where thickened Mississippian sedimentary deposits and adjacent and/or underlying basement rocks are crosscut and offset by numerous normal faults showing mostly minor offsets $(<1 \mathrm{~km})$, whereas thickened wedges of syn-tectonic Pennsylvanian deposits are observed exclusively in the hanging wall of a few major normal faults displaying hundred meter- to kilometerscale offsets (e.g., the Langfjorden-Vargsundet Fault; Koehl et al., 2018a). Similarly, a switch from widespread extension with multiple active faults accommodating small amounts of normal displacement (with slow slip rates) during a phase of rift initiation, to extension localized along a few major fault surfaces (with high slip rates) during interaction and linkage to through-going fault phases was also suggested for Jurassic rifting in the North Sea, where the high-slip-rate Gullfaks- 
Visund Fault (Cowie et al., 2005) may represent a younger offshore analog to the BFZ.

Furthermore, in the NW Barents Sea, a recent seismic study shows thick packages of high-amplitude, south- to southwest-dipping reflections within the Capria Ridge, on the northern flank of the Sørkapp depression (Anell et al., 2016, their Fig. 3a). These are similar to thick seismic packages in the SW Barents Sea (Koehl et al., 2018a) and North Sea (Phillips et al., 2016; Fazlikhani et al., 2017) potentially representing inverted Caledonian shear zones. In the NW Barents Sea, these thick packages of high-amplitude reflections are disrupted by (sub-) parallel (i.e., E-W- to NW-SEstriking), margin-oblique, high-angle brittle normal faults, displaying thick wedges of potential Devonian (?) to Mississippian sedimentary rocks in the hanging wall. These EW- to NW-SE-striking normal faults mostly die out near the base of a thin overlying layer of (uppermost?) Pennsylvanian sedimentary deposits showing relatively constant thickness (Anell et al., 2016). Hence, extensive normal faulting and thickened sedimentary wedges (growth strata?) along deep, margin-oblique, E-W- to NW-SE-striking faults in the NW Barents Sea suggest extensive (collapse-related?) extension in Devonian(?)-Mississippian times and decreasing extension in the Pennsylvanian, which is consistent with field observations in Odellfjellet (Fig. 8b-c). Decreasing extension in the Pennsylvanian is also supported by field observations in central Spitsbergen, suggesting that transgressionregression cycles in Pennsylvanian-Cisuralian deposits were mostly controlled by eustatic sea-level changes and only moderately by active faulting along margin-parallel faults like the BFZ (Samuelsberg and Pickard, 1999).

A WNW-ESE to NW-SE direction was proposed for late Paleozoic extension along the Lofoten-Vesterålen and SW Barents Sea margins in northern Norway (Bergh et al., 2007; Hansen et al., 2012; Indrevær et al., 2013). We therefore believe that Spitsbergen was subjected to a similarly oriented stress field rather than the ENE-WSW extension direction proposed by McCann and Dallmann (1996). We argue that WNW-ESE- to NW-SE-directed late Paleozoic extension in central Spitsbergen may explain the observed upwards dying-out geometry of unsuitably oriented, inherited, basinoblique, WNW-ESE- to NW-SE-striking faults, while N-Sand NE-SW-striking faults accommodated further (EarlyMiddle) Pennsylvanian extensional faulting.

A major difference between margin-oblique faults in Odellfjellet (central Spitsbergen) with their counterparts in northern Norway is that the latter accommodated dominantly lateral post-Caledonian (transfer) movement, e.g., the Trollfjorden-Komagelva Fault Zone (Koehl, 2018a; Koehl et al., 2018c), whereas the former accommodated dominantly normal dip-slip to oblique-slip motions (Figs. 4, 8b-c, and 10d). A tentative explanation might be that inherited, Neoproterozoic, WNW-ESE- to NW-SE-striking brittle faults in central Spitsbergen reactivated as transverse faults (Ogata et al., 2014) in or near the crest of transverse folds reflecting differential displacement along the BFZ (Schlische, 1995) or as accommodation cross faults (Sengör, 1987), as proposed for the WNW-ESE-striking segment of the Troms-Finnmark Fault Complex in the SW Barents Sea (Koehl et al., 2018a). Such interpretations imply that large-scale normal displacement along margin-parallel faults in central Spitsbergen (e.g., the BFZ) initiated in the Mississippian.

\section{Conclusions}

Extensional growth strata in the hanging wall of marginoblique NNE-dipping normal faults and the change from unconformable to interbedded contact between tilted Mississippian coal-bearing sedimentary rocks of the Billefjorden Group and flat-lying to tilted uppermost Mississippianlowermost Pennsylvanian red beds of the Hultberget Formation towards major margin-oblique faults (e.g., the Overgangshytta fault) suggest that the former represent early synrift deposits that were deposited during (Late/latest?) Mississippian extension.

WNW-ESE- to NW-SE-striking faults systematically die out upwards within sedimentary strata of the Billefjorden Group and, occasionally, of the Hultberget Formation. This suggests a switch from widespread extension in the Mississippian, involving faults of as many as three trends (WNWESE, N-S, and possibly NE-SW) during the rift initiation phase, to more localized extension in (Early-Middle?) Pennsylvanian times when normal displacement progressively localized along fewer fault trends (N-S and NE-SW) during the interaction and linkage phase and, eventually, along a few major basin-parallel faults (e.g., Billefjorden Fault Zone) during the through-going fault phase before extension ceased in the Middle-Late Pennsylvanian.

In the Carboniferous, central Spitsbergen was probably subjected to WNW-ESE- to NW-SE-directed extension, thus potentially explaining why unsuitably oriented margin-oblique WNW-ESE-striking faults die out within Mississippian-lowermost Pennsylvanian strata of the Billefjorden Group and Hultberget Formation, while N-S- and NE-SW-striking faults experienced further normal faulting in the Pennsylvanian.

The presence of abundant WNW-ESE-striking faultrelated lineaments in Proterozoic basement rocks east and southeast of Odellfjellet indicates that the formation of Mississippian basin-oblique WNW-ESE-striking normal faults (e.g., Overgangshytta fault) in the Billefjorden Trough may have been controlled by preexisting Neoproterozoic (Timanian?) basement-seated faults.

Basement-seated Neoproterozoic brittle faults possibly reactivated as transverse faults or accommodation cross faults in the crest of transverse folds that reflect differential displacement along the Billefjorden Fault Zone, hence suggesting that normal displacement along major margin-parallel 
faults (like the Billefjorden Fault Zone) initiated in the Mississippian.

The juxtaposition of rocks of the Billefjorden Group in the hanging wall of the Overgangshytta fault, where they form a major anticline, with red beds of the Hultberget Formation in the footwall of the fault possibly indicates that the fault was mildly reactivated as an oblique thrust during Cenozoic transpression-contraction. Alternatively or complementarily, kinematic indicators with a normal sense of shear along the fault suggest that the anticline might have initiated as a growth anticline due to upwards propagation of a preexisting basement-seated fault during (Late/latest?) Mississippian to Early-Middle Pennsylvanian extension.

Bedding-parallel décollements in gently dipping Mississippian (coaly) shale-dominated beds of the Billefjorden Group potentially decoupled unsuitably oriented margin-oblique WNW-ESE-striking faults, preventing further (Pennsylvanian) normal movements along these and, eventually, partially reactivated as duplex-shaped décollements during Cenozoic transpression, largely inhibiting or preventing Cenozoic inversion of steep Mississippian normal faults.

Data availability. The datasets are available upon email request to the main author.

Supplement. The supplement related to this article is available online at: https://doi.org/10.5194/se-9-1535-2018-supplement.

Author contributions. JBPK acquired field measurements, wrote most of the text, and drafted all the figures. JMMB contributed with broadening the scope of the discussion and parts of the outcrop description, leading to the addition of multiple paragraphs to the paper. Contributions are as follows: JBPK (80\%) and JMMB (20\%).

Competing interests. The authors declare that they have no conflict of interest.

Acknowledgements. The present study is part of the ARCEx (Research Centre for Arctic Petroleum Exploration), which is funded by the Research Council of Norway (grant number 228107) together with 10 academic and 8 industry partners. We would like to thank all the persons from these institutions that are involved in this project. We also acknowledge the support of the Arctic Field Grant (grant number 227549) financing helicopter support to and from Odellfjellet. The authors are also grateful to Lars Stemmerik (Natural History Museum of Denmark, København) and Aleksandra Smyrak-Sikora, Snorre Olaussen, and Erik Johannessen (University Centre in Svalbard) for field collaboration, constructive comments, and sharing the aerial photograph used in Supplements 1 and 2. The authors also thank Luisa Campiño (Equinor), Alvar Braathen (University of Oslo), and Winfried Dallmann (UiT
The Arctic University of Norway in Troms $\varnothing$ ) for fruitful discussion that contributed to improving the paper.Finally, the authors acknowledge the input of the reviewers Alexander Peace and Antje Lenhart whose relevant comments were highly appreciated.

Edited by: Mark Allen

Reviewed by: Antje Lenhart and Alexander L. Peace

\section{References}

Anell, I., Faleide, J. I., and Braathen, A.: Regional tectonosedimentary development of the highs and basins of the northwestern Barents Shelf, Norsk Geol. Tidsskr., 96, 27-41, 2016.

Balashov, Yu. A., Larionov, A. N., Gannibal, L. F., Sirotkin, A. N., Tebenkov, A. M., Ryüngenen, G. I., and Ohta, Y.: An Early Proterozoic $\mathrm{U}-\mathrm{Pb}$ zircon age from an Eskolabreen Formation gneiss in southern Ny Friesland, Spitsbergen, Polar Res., 12, 147-152, 1993.

Bastesen, E. and Braathen, A.: Extensional faults in fine grained carbonates - analysis of fault core lithology and thicknessdisplacement relationships, J. Struct. Geol., 32, 1609-1628, 2010.

Bergh, S. G. and Grogan, P.: Tertiary structure of the SørkappHornsund Region, South Spitsbergen, and implications for the offshore southern continuation of the fold-thrust Belt, Norsk Geol. Tidsskr., 83, 43-60, 2003.

Bergh S. G., Braathen, A., and Andresen, A.: Interaction of Basement-Involved and Thin-Skinned Tectonism in the Tertiary Fold-Thrust Belt of Central Spitsbergen, Svalbard, AAPG Bulletin, 81, 637-661, 1997.

Bergh, S. G., Maher Jr., H. D., and Braathen, A.: Tertiary divergent thrust directions from partitioned transpression, Brøggerhalvøya, Spitsbergen, Norsk Geol. Tidsskr., 80, 63-82, 2000.

Bergh, S. G., Eig, K., Kløvjan, O. S., Henningsen, T., Olesen, O., and Hansen, J.-A.: The Lofoten-Vesterålen continental margin: a multiphase Mesozoic-Palaeogene rifted shelf as shown by offshore-onshore brittle fault-fracture analysis, Norsk Geol. Tidsskr., 87, 29-58, 2007.

Bergh, S. G., Maher Jr., H. D., and Braathen, A.: Late Devonian transpressional tectonics in Spitsbergen, Svalbard, and implications for basement uplift of the Sørkapp-Hornsund High, J. Geol. Soc. London, 168, 441-456, 2011.

Bergh, S. G., Sylvester, A. G., Damte, A., and Indrevær, K.: Evolving transpressional strain fields along the San Andreas fault in southern California: implications for fault branching, fault dip segmentation and strain partitioning, EGU General Assembly 2014, 27 April-2 May, Vienna, Austria, 2014.

Bergh, S. G., Sylvester, A. G., Damte, A., and Indrevær, K.: Polyphase kinematic history of transpression along the Mecca Hills segment of the San Andreas fault, southern California, Geosphere, submitted, 2018.

Birkenmayer, K. and Turnau, E.: Lower Carboniferous age of the so-called Wijde Bay Series in Hornsund, Vestspitsbergen, Nor. Polarinst. Årb. 1961, 41-61, 1962.

Blinova, M., Faleide, J. I., Gabrielsen, R. H., and Mjelde, R.: Seafloor expression and shallow structure of a fold-and-thrust system, Isfjorden, west Spitsbergen, Polar Res., 31, 11209, https://doi.org/10.3402/polar.v3110.11209, 2012. 
Blinova, M., Faleide, J. I., Gabrielsen, R. H., and Mjelde, R.: Analysis of structural trends of sub-sea-floor strata in the Isfjorden area of the West Spitsbergen Fold-and-Thrust Belt based on multichannel seismic data, J. Geol. Soc. London, 170, 657-668, 2013.

Braathen, A. and Bergh, S. G.: Kinematics of Tertiary deformation in the basement-involved fold-thrust complex, western Nordenskiøld Land, Svalbard: tectonic implications based on fault-slip data analysis, Tectonophysics, 249, 1-29, 1995.

Braathen, A., Maher Jr., H. D., Haabet, T. E., Kristensen, S. E., Tørudbakken, B. O., and Worsley, D.: Caledonian thrusting on Bjørnøya: implications for Palaeozoic and Mesozoic tectonism of the western Barents Shelf, Norsk Geol. Tidsskr., 79, 57-68, 1999.

Braathen, A., Bælum, K., Maher Jr., H. D., and Buckley, S. J.: Growth of extensional faults and folds during deposition of an evaporite-dominated half-graben basin; the Carboniferous Billefjorden Trough, Svalbard, Norsk Geol. Tidsskr., 91, 137-160, 2011.

Braathen, A., Osmundsen, P. T., Maher Jr., H. D., and Ganerød, M.: The Keisarhjelmen detachment records Silurian-Devonian extensional collapse in Northern Svalbard, Terra Nova, 30, 34 39, 2018.

Bugge, T., Mangerud, G., Elvebakk, G., Mørk, A., Nilsson, I., Fanavoll, S., and Vigran, J. O.: The Upper Palaeozoic succession on the Finnmark Platform, Barents Sea, Norsk Geologisk Tidsskrift, 75, 3-30, 1995.

Cawood, P. A. and Pisarevsky, S. A.: Laurentia-Baltica-Amazonia relations during Rodinia assembly, Precambrian Res., 292, 386397, 2017

Cawood, P. A., McCausland, P. J. A., and Dunning, G. R.: Opening Iapetus: Constraints from the Laurentian margin in Newfoundland, GSA Bulletin, 113, 443-453, 2001.

Cawood, P. A., Strachan, R., Cutts, K., Kinny, P. D., Hand, M., and Pisarevsky, S.: Neoproterozoic orogeny along the margin of Rodinian: Valhalla orogeny, North Atlantic, Geology, 38, 99-102, 2010.

Childs, C., Manzocchi, T., Walsh, J. J., Bonson, C. G., Nicol, A., and Schöpfer, M. P. J.: A geometric model of fault zone and fault rock thickness variations, J. Struct. Geol., 31, 117-127, 2009.

Christophersen, G.: Fracturing and Weathering in Basement of the Billefjorden Trough, an Analogue to Top Basement Reservoirs, unpublished Master's Thesis, University of Troms $\varnothing$, Troms $\varnothing$, Norway, 137 pp., 2015.

Cowie, P. A., Underhill, J. R., Behn, M. D., Lin, J., and Gill, C. E.: Spatio-temporal evolution of strain accumulation derived from multi-scale observations of Late Jurassic rifting in the northern North Sea: A critical test of models for lithospheric extension, Earth Planet. Sc. Lett., 234, 401-419, 2005

Cutbill, J. L. and Challinor, A.: Revision of the Stratigraphical Scheme for the Carboniferous and Permian of Spitsbergen and Bjørnøya, Geol. Mag., 102, 418-439, 1965.

Cutbill, J. L., Henderson, W. G., and Wright, N. J. R.: The Billefjorden Group (Early Carboniferous) of central Spitsbergen, Norsk Polarinst. Skr., 164, 57-89, 1976.

Dallmann, W. K.: Lithostratigraphic Lexicon of Svalbard, edited by: Dallmann, W. K., Norwegian Polar Institute, Polar Environmental Centre, Tromsø, Norway, 1999.
Dallmann, W. K., Andresen, A., Bergh, S. G., Maher Jr., H. D., and Ohta, Y.: Tertiary fold-and-thrust belt of Spitsbergen, Svalbard, Norsk Polarinstitutt Meddelelser, 128, 51 pp., 1993.

Davids, C., Wemmer, K., Zwingmann, H., Kohlmann, F., Jacobs, J., and Bergh, S. G.: K-Ar illite and apatite fission track constraints on brittle faulting and the evolution of the northern Norwegian passive margin, Tectonophysics, 608, 196-211, 2013.

Dißmann, B. and Grewing, A.: Post-svalbardische kompressive Strukturen im westlichen Dickson Land (Hugindalen), ZentralSpitzbergen, Münster, Forsch. Geol. Paläont., 82, 235-242, 1997.

Fairchild, I. J.: The Orustdalen Formation of Brøggerhalvøya, Svalbard: A fan delta complex of Dinantian/Namurian age, Polar Res., 1, 17-34, 1982.

Fazlikhani, H., Fossen, H., Gawthorpe, R. L., Faleide, J. I., and Bell, R.: Basement structure and its influence on the northern North Sea rift, Tectonics, 36, 1151-1177, 2017.

Forslund, T. and Gudmundsson, A.: Structure of Tertiary and Pleistocene normal faults in Iceland, Tectonics, 11, 57-68, 1992.

Gabrielsen, R. H., Færseth, R. B., Jensen, L. N., Kalheim, J. E., and Riis, F.: Structural elements of the Norwegian continental shelf, Part I: The Barents Sea Region, Norwegian Petroleum Directorate Bulletin, 6, 1-33, 1990.

Gawthorpe, R. L. and Leeder, M. R.: Tectono-sedimentary evolution of active extensional basins, Basin Res., 12, 195-218, 2000.

Gawthorpe, R. L., Sharp, I., Underhill, J. R., and Gupta, S.: Linked sequence stratigraphic and structural evolution of propagating normal faults, Geology, 25, 795-798, 1997.

Gee, D. G.: Late Caledonian (Haakonian) movements in northern Spitsbergen, Nor. Polarinst. Årb. 1970, 92-101, 1972.

Gee, D. G., Harland, W. B., and McWhae, J. R. H.: Geology of Central Vestspitsbergen: Part I. Review of the geology of Spitsbergen, with special reference to Central Vestspitsbergen; Part II. Carboniferous to Lower Permian of Billefjorden, Trans. Roy. Soc. Edinb., 62, 299-356, 1952.

Gjelberg, J. G.: Upper Devonian (Famennian) - Middle Carboniferous succession of Bjørnøya, a study of ancient alluvial and coastal marine sedimentation, Norsk Polarinst. Skr., 174, 67 pp., 1981.

Gjelberg, J. G.: Early-Middle Carboniferous sedimentation on Svalbard. A study of ancient alluvial and coastal marine sedimentation in rift- and strike-slip basins, $\mathrm{PhD}$ thesis, University of Bergen, 306 pp., 1984.

Gjelberg, J. G. and Steel, R. J.: An outline of Lower-Middle Carboniferous sedimentation on Svalbard: Effects of tectonic, climatic and sea level changes in rift basin sequences, in: Geology of the North Atlantic Borderlands, edited by: Kerr, J. W. and Ferguson, A. J., Can. Soc. Of Petrol. Geol. Mem., 7, 543-561, 1981.

Gjelberg, J. G. and Steel, R. J.: Middle Carboniferous marine transgression, Bjørnøya, Svalbard: facies sequences from an interplay of sea level changes and tectonics, Geol. J., 18, 1-19, 1983.

Gudlaugsson, S. T., Faleide, J. I., Johansen, S. E., and Breivik, A. J.: Late Palaeozoic structural development of the South-western Barents Sea, Mar. Petrol. Geol., 15, 73-102, 1998.

Gudmundsson, A.: Fracture dimensions, displacements and fluid transport, J. Struct. Geol., 22, 1221-1231, 2000.

Hallett, B. W., McClelland, W. C., and Gilotti, J. A.: The Timing of Strike-Slip Deformation Along the Storstrømmen Shear Zone, 
Greenland Caledonides: U-Pb Zircon and Titanite Geochronology, Geoscience Canada, 41, 19-45, 2014.

Hansen, J.-A., Bergh, S. G., and Henningsen, T.: Mesozoic rifting and basin evolution on the Lofoten and Vesterålen Margin, North-Norway; time constraints and regional implications, Norsk Geol. Tidsskr., 91, 203-228, 2012.

Haq, B. U. and Schutter, R.: A Chronology of Paleozoic Sea-Level Changes, Science, 322, 64-68, 2008.

Haremo, P., Andresen, A., Dypvik, H., Nagy, J., Elverhøi, A., Eikeland, T. A., and Johansen, H.: Structural development along the Billefjorden Fault Zone in the area between Kjellströmdalen and Adventdalen/Sassendalen, central Spitsbergen, Polar Res., 8, 195-216, 1990.

Harland, W. B.: Contribution of Spitsbergen to understanding of tectonic evolution of North Atlantic region, AAPG Memoir, 12, 817-851, 1969.

Harland, W. B. and Wright, N. J. R.: Alternative hypothesis for the pre-Caledonian evolution of Svalbard, Nor. Polarinst. Skr., 167, 89-117, 1979.

Harland, W. B., Wallis, R. H., and Gayer, R. A.: A Revision of the Lower Hecla Hoek succession in Central North Spitsbergen and correlation elsewhere, Geol. Mag., 103, 70-97, 1966.

Harland, W. B., Cutbill, L. J., Friend, P. F., Gobbett, D. J., Holliday, D. W., Maton, P. I., Parker, J. R., and Wallis, R. H.: The Billefjorden Fault Zone, Spitsbergen - the long history of a major tectonic lineament, Norsk Polarinst. Skr., 161, 1-72, 1974.

Hartz, E. H. and Torsvik, T. H.: Carboniferous age for the East Greenland "Devonian" basin: Paleomagnetic and isotopic constraints on age, stratigraphy, and plate reconstructions, Geology, 25, 675-678, 1997.

Holliday, D. W. and Cutbill, L. J.: The Ebbadalen Formation (Carboniferous) of Spitsbergen, Proc. Yorks. Geol. Soc., 39, 1-32, 1972.

Indrevær, K., Bergh, S. G., Koehl, J.-B., Hansen, J.-A., Schermer, E. R., and Ingebrigtsen, A.: Post-Caledonian brittle fault zones on the hyperextended SW Barents Sea margin: New insights into onshore and offshore margin architecture, Norsk Geol. Tidsskr., 93, 167-188, 2013.

Johannessen, E. P.: Facies analysis of the Ebbadalen Formation, Middle Carboniferous, Billefjorden Trough, Spitsbergen, unpublished Master's Thesis, University of Bergen, Bergen, Norway, 314 pp., 1980.

Johannessen, E. P. and Steel, R. J.: Mid-Carboniferous extension and rift-infill sequences in the Billefjorden Trough, Svalbard, Norsk Geol. Tidsskr., 72, 35-48, 1992.

Johannessen, M. U.: Fault core and its geostatistical analysis: Insight into the fault core thickness and fault displacement, Master's Thesis, University of Bergen, Bergen, Norway, 141 pp., 2017.

Johansson, $\AA$ and Gee, D. G.: The late Palaeoproterozoic Eskolabreen granitoids of southern Ny Friesland, Svalbard Caledonides - geochemistry, age, and origin, GFF, 121, 113-126, 1999.

Klein, A. C. and Steltenpohl, M. G.: Basement-cover relations and late- to post-Caledonian extension in the Leknes group, west-central Vestvågøy, Lofoten, north Norway, Norsk Geologisk Tidsskrift, 79, 19-31, 1999.

Klein, A. C., Steltenpohl, M. G., Hames, W. E., and Andresen, A.: Ductile and brittle extension in the southern Lofoten archipelago, north Norway: implications for differences in tectonic style along an ancient collisional margin, American J. Sci., 299, 69-89, 1999.

Klitzke, P., Franke, D., Ehrhardt, A., Lutz, R., Reinhardt, L., Heyde, I., and Faleide, J. I.: The Paleozoic evolution of the Olga basin, northern Barents Sea - a link to the Timanian Orogeny?, Geochem. Geophys. Geosyst., submitted, 2018a.

Klitzke, P., Franke, D., Lutz, R., Ehrhardt, Reinhardt, L., and Berglar, K.: The Olga Basin (northern Barents Sea) - a Caledonian or Timanian affinity?, AAPG European Regional Conference - Global Analogues for the Atlantic Margin, 2-3 May, Lisbon, Portugal, 2018b.

Koehl, J.-B. P.: Mid/Late Devonian-Carboniferous extensional faulting in Finnmark and the SW Barents Sea, PhD Thesis, University of Troms $\varnothing$, Troms $\varnothing$, Norway, 210 pp., 2018a.

Koehl, J.-B. P.: Carboniferous tectonic history of Bjørnøya, Norsk Geol. Tidsskr., in preparation, 2018b.

Koehl, J.-B. P., Bergh, S. G., Brown, J., and Sylvester, A.: Evolution of the southeasternmost Indio Hills along the San Andreas Fault in southern California, unpublished internal report, University of Troms $\varnothing$, Troms $\varnothing$, Norway, 36 pp., 2017.

Koehl, J.-B. P., Bergh, S. G., Henningsen, T., and Faleide, J. I.: Middle to Late Devonian-Carboniferous collapse basins on the Finnmark Platform and in the southwesternmost Nordkapp basin, SW Barents Sea, Solid Earth, 9, 341-372, https://doi.org/10.5194/se9-341-2018, 2018a.

Koehl, J.-B. P., Bergh, S. G., and Wemmer, K.: Neoproterozoic and post-Caledonian exhumation and shallow faulting in NW Finnmark from $\mathrm{K}-\mathrm{Ar}$ dating and $p / T$ analysis of fault rocks, Solid Earth, 9, 923-951, https://doi.org/10.5194/se-9-923-2018, 2018b.

Koehl, J.-B. P., Bergh, S. G., Osmundsen, P. T., Redfield, T. F., Indrevær, K., Lea, H., and Bergø, E.: Late DevonianCarboniferous faulting and controlling fabrics in NW Finnmark, Norsk Geol. Tidsskr., submitted, 2018c.

Kolyukhin, D. and Torabi, A.: Statistical analysis of the relationships between faults attributes, J. Geophys. Res., 117, 1-14, 2012.

Labrousse, L., Elvevold, S., Lepvrier, C., and Agard, P.: Structural analysis of high-pressure metamorphic rocks of Svalbard: Reconstructing the early stages of the Caledonian orogeny, Tectonics, 27, https://doi.org/10.1029/2007TC002249, 2008.

Lamar, D. L. and Douglass, D. N.: Geology of an area astride the Billefjorden Fault Zone, northern Dicksonland, Spitsbergen, Svalbard, Norsk Polarinst. Skr., 197, 1-43, 1995.

Larssen, G. B., Elvebakk, G., Henriksen, S. E., Nilsson, I., Samuelsberg, T. J., Svånå, T. A., Stemmerik, L., and Worsley, D.: Upper Palaeozoic lithostratigraphy of the Southern Norwegian Barents Sea, Norwegian Petroleum Directorate Bulletin, 9, 1-76, 2002.

Leever, K. A., Gabrielsen, R. H., Faleide, J. I., and Braathen, A.: A transpressional origin for the West Spitsbergen foldand-thrust belt: Insight from analog modelling, Tectonics, 30, https://doi.org/10.1029/2010TC002753, 2011.

Lippard, S. J. and Prestvik, T.: Carboniferous dolerite dykes on Magerøy: new age determination and tectonic significance, Norsk Geologisk Tidsskrift, 77, 159-163, 1997.

Lønøy, A.: A Mid-Carboniferous, carbonate-dominated platform, Central Spitsbergen, Norsk Geol. Tidsskr., 75, 48-63, 1995. 
Lowell, J. D.: Spitsbergen Tertiary Orogenic Belt and the Spitsbergen Fracture Zone, Geol. Soc. Am. Bul., 83, 3091-3102, 1972.

Maher Jr., H. D.: Atypical rifting during the Carboniferous if the NW Barents Shelf. Report for Saga Petroleum 11/96, 1996.

Maher Jr., H. D. and Braathen, A.: Løvehovden fault and Billefjorden rift basin segmentation and development, Spitsbergen, Norway, Geol. Mag., 148, 154-170, 2011.

Majka, J., Czerny, J., Mazur, S., Holm, D. K., and Manecki, M.: Neoproterozoic metamorphic evolution of the Isbjørnhamna Group rocks from south-western Svalbard, Polar Res., 29, 250264, 2010

Manby, G. M. and Lyberis, N.: Tectonic evolution of the Devonian Basin of northern Svalbard, Norsk Geol. Tidsskr., 72, 7-19, 1992.

Manby, G. M., Lyberis, N., Chorowicz, J., and Thiedig, F.: PostCaledonian tectonics along the Billefjorden fault zone, Svalbard, and implications for the Arctic region, Geol. Soc. Am. Bul., 105, 201-216, 1994

Marks, L. and Wysokinski, L.: Early Holocene Glacier Advance in the Austfjorden Region, Northern Spitsbergen, B. Pol. Aca. Sci.Earth, 34, 437-446, 1986.

Mazur, S., Czerny, J., Majka, J., Manecki, M., Holm, D., Smyrak, A., and Wypych, A.: A strike-slip terrane boundary in Wedel Jarlsberg Land, Svalbard, and its bearing on correlations pf SW Spitsbergen with the Pearya terrane and Timanide belt, J. Geol. Soc. London, 166, 529-544, 2009

McCann, A. J.: Deformation of the Old Red Sandstone of NW Spitsbergen; links to the Ellesmerian and Caledonian orogenies, in: New Perspectives on the Old Red Sandstone, edited by: Friends, P. F. and Williams, B. P. J., Geological Society, London, 180, 567-584, 2000.

McCann, A. J. and Dallmann, W. K.: Reactivation of the long-lived Billefjorden Fault Zone in north central Spitsbergen, Svalbard, Geological Magazine, 133, 63-84, 1996.

McClelland, W. C., Gilotti, J. A., Ramarao, T., Stemmerik, L., and Dalhoff, F.: Carboniferous basin in Holm Land records local exhumation of the North-East Greenland Caledonides: Implications for the detrital zircon signature of a collisional orogeny, Geosphere, 12, 925-947, 2016.

McWhae, J. R. H.: The major fault zone of central Vestspitzbergen, Q. J. Geol. Soc. Lon., 108, 209-232, 1953.

Mørk, A., Knarud, R., and Worsley, D.: Depositional and diagenetic environments of the Triassic and Lower Jurassic succession of Svalbard, Canadian Society of Petroleum Geologists Memoir, 8, 371-391, 1982.

Nasuti, A., Roberts, D., and Gernigon, L.: Multiphase mafic dykes in the Caledonides of northern Finnmark revealed by a new highresolution aeromagnetic dataset, Norsk Geol. Tidsskr., 95, 251263, 2015

Nemec, W., Steel, R. J., Gjelberg, J., Collinson, J. D., Prestholm, E., and Øxnevad, I. E.: Anatomy of Collapsed and Re-established Delta Front in Lower Cretaceous of Eastern Spitsbergen: Gravitational Sliding and Sedimentation Processes, AAPG Bulletin, 72, 454-476, 1988.

Nicol, A., Watterson, J., Walsh, J. J., and Childs, C.: The shapes, major axis orientations and displacement patterns of fault surfaces, J. Struct. Geol., 18, 235-248, 1995.

Nøttvedt, A., Cecchi, M., Gjelberg, J. G., Kristensen, S. E., Lønøy, A., Rasmussen, A., Rasmussen, E., Skott, P. H., and van Veen,
P. M.: Svalbard-Barents Sea correlation: a short review, in: Arctic Geology and Petroleum Potential, edited by: Vorren, T. O., Bergsager, E., Dahl-Stamnes, Ø. A., Holter, E., Johansen, B., Lie, E., and Lund, T. B., Norwegian Petroleum Society (NPF), Special Publication, 2, 363-375, Amsterdam, 1993.

Ogata, K., Senger, K., Braathen, A., and Tveranger, J.: Fracture corridors as seal-bypss systems in siliciclastic reservoir-cap rock successions: Field-based insights from the Jurassic Entrada Formation (SE Utah, USA), J. Struct. Geol., 66, 162-187, 2014.

Ohta, Y., Dallmeyer, R. D., and Peucat, J. J.: Caledonian terranes in Svalbard, Geological Society Of America, Special Paper, 230, $1-15,1989$.

Onderdonk, N. and Midtkandal, I.: Mechanisms of collapse of the Cretaceous Helvetiafjellet Formation at Kvalvågen, eastern Spitsbergen, Mar. Petrol. Geol., 27, 2118-2140, 2010.

Osmundsen, P.-T. and Andersen, T. B.: The middle Devonian basins of western Norway: sedimentary response to large-scale transtensional tectonics, Tectonophysics, 332, 51-68, 2001.

Osmundsen, P.-T., Braathen, A., Rød, R. S., and Hynne, I. B.: Styles of normal faulting and fault-controlled sedimentation in the Triassic deposits of Eastern Svalbard, Norwegian Petroleum directorate Bulletin, 10, 61-79, 2014.

Phillips, T., Jackson, C. A-L., Bell, R. E., Duffy, O. B., and Fossen, H.: Reactivation of intrabasement structures during rifting: A case study from offshore southern Norway, J. Struct. Geol., 91, 54-73, 2016.

Piepjohn, K.: The Svalbardian-Ellesmerian deformation of the Old Red Sandstone and the pre-Devonian basement in NW Spitsbergen (Svalbard), in: New Perspectives on the Old Red Sandstone, edited by: Friends, P. F. and Williams, B. P. J., Geological Society, London, 180, 585-601, 2000.

Piepjohn, K., von Gosen, W., Tessensohn, F., Reinhardt, L., McClelland, W. C., Dallmann, W. D., Gaedicke, C., and Harrison, J. C.: Tectonic map of the Ellesmerian and Eurekan deformation belts on Svalbard, North Greenland, and the Queen Elizabeth Islands (Canadian Arctic), Arktos, 1, https://doi.org/10.1007/s41063015-0015-7, 2015.

Playford, G.: Lower Carboniferous microfloras of Spitsbergen, Paleontology, 5, 550-618, 1962.

Prestholm, E. and Walderhaug, O.: Synsedimentary Faulting in a Mesozoic Deltaic Sequence, Svalbard, Arctic Norway-Fault Geometries, Faulting Mechanisms, and Sealing Properties, AAPG Bulletin, 84, 505-522, 2000.

Prosser, S.: Rift-related linked depositional systems and their seismic expression, in: Tectonic and Seismic Sequence Stratigraphy, edited by: Williams, G. D. and Dobb, A., Geological Society Special Publication, 71, 35-66, 1993.

Rice, A. H. N.: Restoration of the External Caledonides, Finnmark, North Norway, in: New Perspective on the Caledonides of Scandinavia and Related Areas, edited by: Corfu, F., Gasser, D., and Chew, D. M., Geological Society, London, UK, Special Publications, 390, 271-299, 2013.

Roberts, D. and Olovyanishnikov, V.: Structural and tectonic development of the Timanide orogeny, in: The Neoproterozoic Timanide Orogen of Eastern Baltica, edited by: Gee, D. G. and Pease, V., Geological Society, London, Memoirs, 30, 47-57, 2004.

Roberts, D. and Siedlecka, A.: Timanian orogenic deformation along the northeastern margin of Baltica, Northwest Russia 
and Northeast Norway. And Avalonian-Cadomian connections, Tectonophysics, 352, 169-184, 2002.

Roberts, D., Mitchell, J. G., and Andersen, T. B.: A post-Caledonian dyke from Magerøy North Norway: age and geochemistry, Norsk Geol. Tidsskr., 71, 289-294, 1991.

Rotevatn, A. and Jackson, C. A. L.: 3D structure and evolution of folds during normal fault dip linkage, J. Geol. Soc. London, 171, 821-829, 2014.

Rotevatn, A., Kristensen, T. B., Ksienzyk, A. K., Wemmer, K., Henstra, G. A., Midkandal, I., Grundvåg, S.-A., and Andresen, A.: Structural inheritance and rapid rift-length establishment in a multiphase rift: the East Greenland rift system and its Caledonian orogenic ancestry, Tectonics, 37, 1858-1875, https://doi.org/10.1029/2018TC005018, 2018.

Samuelsberg, T. J. and Pickard, N. A. H.: Upper Carboniferous to Lower Permian transgressive-regressive sequences of central Spitsbergen, Arctic Norway, Geol. J., 34, 393-411, 1999.

Samuelsberg, T. J., Elvebakk, G., and Stemmrik, L.: Late Paleozoic evolution of the Finnmark Platform, southern Norwegian Barents Sea, Norsk Geol. Tidsskr., 83, 351-362, 2003.

Sartini-Rideout, C., Gilotti, J. A., and McClelland, W. C.: Geology and timing of dextral strike-slip shear zones in Danmarkshavn, North-East Greenland Caledonides, Geological Magazine, 143, 431-446, 2006.

Saunders, W. B. and Ramsbottom, W. H. C.: The midCarboniferous eustatic event, Geology, 14, 208-212, 1986.

Scheibner, C., Blomeier, D., Forke, H., and Gesierich, K.: From terrestrial to shallow-marine depositional environments: reconstruction of the depositional environments during the Late Carboniferous transgression of the Lomfjorden Trough in NE Spitsbergen (Malte Brunfjellet Formation), Norsk Geol. Tidskr., 95, 127-152, 2015.

Schlische, R. W.: Geometry and Origin of Fault-Related Folds in Extensional Settings, AAPG Bulletin, 79, 1661-1678, 1995.

Schlische, R. W., Young, S. S., Ackermann, R. V., and Gupta, A.: Geometry and scaling relations of a population of very small riftrelated normal faults, Geology, 24, 683-686, 1996.

Sengör, A. M. C.: Cross-faults and differential stretching of hanging walls in regions of low-angle normal faulting: examples from western Turkey, in: Continental Extensional Tectonics, edited by: Coward, M. P., Dewey, J. F., and Hancock P. L., Geological Society Special Publication, 28, 575-589, 1987.

Séranne, M., Chauvet, A., Seguret, M., and Brunel, M.: Tectonics of the Devonian collapse-basins of western Norway, Bull. Soc. Géol. Fr., 8, 489-499, 1989.

Siedlecka, A.: Late Precambrian Stratigraphy and Structure of the North-Eastern Margin of the Fennoscandian Shield (East Finnmark - Timan Region), Nor. Geol. Unders., 316, 313-348, 1975.
Siedlecka, A. and Siedlecki, S.: Some new aspects of the geology of Varanger peninsula (Northern Norway), Nor. Geol. Unders., 247, 288-306, 1967.

Siedlecki, S.: Geologisk kart over Norge, berggrunnskart Vads $\emptyset$ M 1 : 250000, Nor. Geol. Unders., 1980.

Steel, R. J. and Worsley, D.: Svalbard's post-Caledonian strata an atlas of sedimentational patterns and palaeogeographic evolution, in: Petroleum Geology of the North European Margin, Norwegian Petroleum Society (NPF), Graham and Trotman, 109$135,1984$.

Steltenpohl, M. G., Moecher, D., Andresen, A., Ball, J., Mager, S., and Hames, W. E.: The Eidsfjord shear zone, LofotenVesterålen, north Norway: An Early Devonian, paleoseismogenic low-angle normal fault, J. Struct. Geol., 33, 1023-1043, 2011.

Torgersen, E., Viola, G., Zwingmann, H., and Harris, C.: Structural and temporal evolution of a reactivated brittle-ductile fault - Part II: Timing of fault initiation and reactivation by $\mathrm{K}-\mathrm{Ar}$ dating of synkinematic illite/muscovite, Earth Planet. Sc. Lett., 407, 221 233, 2014.

Torsvik, T. H., Smethurst, M. A., Meert, J. G., Van der Voo, R., McKerrow, W. S., Brasier, M. D., Sturt, B. A., and Walderhaug, H. J.: Continental break-up and collision in the Neoproterozoic and Palaeozoic - A tale of Baltica and Laurentia, Earth-Sci. Rev., 40, 229-258, 1996.

Watterson, J.: Fault dimensions, Displacements and Growth, Pure Appl. Geoph., 124, 365-373, 1986.

Wilkins, S. J. and Gross, M. R.: Normal fault growth in layered rocks at Split Mountain, Utah: influence of mechanical stratigraphy on dip linkage, fault restriction and fault scaling, J. Struct. Geol., 24, 1413-1429, 2002.

Witt-Nilsson, P., Gee, D. G., and Hellman, F. J.: Tectonostratigraphy of the Caledonian Atomfjella Antiform of northern Ny Friesland, Svalbard, Norsk Geol. Tidsskr., 78, 67-80, 1998.

Woodcock, N. H. and Mort, K.: Classification of fault breccias and related fault rocks, Geol. Mag., 145, 435-440, 2008.

Worsley, D. and Mørk, A.: The Triassic stratigraphy of southern Spitsbergen, Nor. Polarinst. Årb., 1977, 43-60, 1978.

Worsley, D., Agdestein, T., Gjelberg, J. G., Kirkemo, K., Mørk, A., Nilsson, I., Olaussen, S., Steel, R. J., and Stemmerik, L.: The geological evolution of Bjørnøya, Arctic Norway: implications for the Barents Shelf, Norsk Geol. Tidsskr., 81, 195-234, 2001.

Ziegler, P. A., Bertotti, G., and Cloetingh, S.: Dynamic processes controlling foreland development - the role of mechanical (de)coupling of orogenic wedges and forelands, EGU Stephan Mueller, Special Publication Series, 1, 17-56, 2002. 